3-1-2015

\title{
Do Mutual Funds Herd in Industries?
}

\author{
Umut Celiker \\ u.celiker@csuohio.edu \\ Jaideep Chowdhury \\ Sokhan Sonaer
}

Follow this and additional works at: https://engagedscholarship.csuohio.edu/bus_facpub

Part of the Finance and Financial Management Commons

How does access to this work benefit you? Let us know!

\section{Publisher's Statement}

NOTICE: this is the author's version of a work that was accepted for publication in the Journal of Banking and Finance. Changes resulting from the publishing process, such as peer review, editing, corrections, structural formatting, and other quality control mechanisms may not be reflected in this document. Changes may have been made to this work since it was submitted for publication. A definitive version was subsequently published in the Journal of Banking and Finance, 52, 03-01-2015; 10.1016/j.jbankfin.2014.11.006

\section{Recommended Citation}

Celiker, Umut; Chowdhury, Jaideep; and Sonaer, Sokhan, "Do Mutual Funds Herd in Industries?" (2015). Business Faculty Publications. 256.

https://engagedscholarship.csuohio.edu/bus_facpub/256

This Article is brought to you for free and open access by the Monte Ahuja College of Business at EngagedScholarship@CSU. It has been accepted for inclusion in Business Faculty Publications by an authorized administrator of EngagedScholarship@CSU. For more information, please contact library.es@csuohio.edu. 


\title{
Do mutual funds herd in industries?
}

\author{
Umut Celiker $^{\mathrm{a}, \mathrm{b}, 1}$, Jaideep Chowdhury ${ }^{\mathrm{c}, 2}$, Gokhan Sonaer ${ }^{\mathrm{d}, *}$
}

\section{Introduction}

Herding is commonly defined as the similarities in trading of a group of market participants. Previous studies propose two main micro-level herding measures to examine evidence of herding of a group of market participants. ${ }^{3}$ Lakonishok et al. (1992, hereafter LSV) construct a herding measure that detects quarterly imbalances in the number of buyers and sellers from a particular group in specific stocks while Sias (2004, hereafter Sias) proposes a measure that quantifies the degree to which such imbalances tend to persist over adjacent quarters. In this paper, we use the two herding measures to investigate whether mutual funds herd in industries and the possible effects of such behavior on industry returns.

The extant literature provide mixed evidence of herding using either one of the two proposed herding measures. LSV report weak evidence of herding by pension funds in individual stocks and find no evidence that such herding has a destabilizing effect on stock prices. Likewise, Grinblatt et al. (1995, hereafter GTW) use the LSV measure to examine mutual fund herding in individual stocks and report weak herding levels. Wermers (1999) carries out a similar analysis on a larger sample of mutual funds and finds similar evidence of herding. In addition, he documents that stocks that are subjected to buy herding outperform stocks that are subjected to sell herding both in the herding quarter and in the following two quarters. Sias uses his above mentioned alternative herding measure and finds strong evidence of herding by institutions in individual stocks.

The above surveyed studies focus on stock herding and on the effect that such herding may have on the returns of stocks. Different from the above literature, a related recent study by Choi and Sias (2009) investigates industry herding by institutional investors. They provide several justifications for their focus on herding at the industry level. They first contend that the reasons that may motivate institutions to herd in individual stocks may also lead them 
to herd at the industry level. ${ }^{4}$ Second, they cite evidence in the literature that information is not incorporated simultaneously in the prices of all stocks in the same industry, and that investors can therefore infer information about a given stock from other stocks in the same industry. ${ }^{5}$ Employing the Sias measure Choi and Sias (2009) find high levels of industry herding by institutional investors but document only weak evidence that industries that are subjected to high levels of herding exhibit subsequent price reversals.

This study examines whether mutual funds herd in industries and the extent to which such herding impacts industry valuations. Although this study shares a similar motivation to that offered by Choi and Sias (2009) in investigating herding in industries, it focuses on herding by mutual funds rather than institutions. ${ }^{6}$ The focus on mutual funds is motivated by the following reasons. First, it is well documented that mutual funds have tendencies to follow certain behavioral patterns that might result in herding. Specifically, previous studies show that mutual funds tend to chase certain characteristics (Falkenstein, 1996), mimic the trades of other funds with good performance (Friend et al., 1970), trade due to reputational concerns (Chevalier and Ellison, 1999), and trade on the same new information (Brown et al., 2014). These types of behaviors may also drive mutual funds to herd in industries. Second, there are data related advantages of focusing on mutual funds rather than focusing on all institutions. Institutional holdings data (13-F filings) are reported at the fund family level whereas Thomson-Reuters Mutual Fund holdings data are available at the fund level. Using the latter we can filter out index funds and sector funds from our sample. In addition, a fund family can be comprised of funds that trade with the herd, against the herd, and/or independently. Mutual funds holdings database enables us to detect these differences in trading behaviors of individual funds belonging to the same fund family.

To investigate whether mutual funds herd in industries, this study employs both the LSV and the Sias herding measures. The LSV measure, as applied to industries, quantifies the imbalance between the number of buyers and sellers from a particular investor group in a specific industry during a given quarter. In contrast, the Sias measure quantifies the degree to which members of an investor group (mutual funds in our study) follow each other's industry trades in adjacent quarters. Using the LSV measure we find that the level of industry herding by mutual funds is statistically significant for the 1980-2013 period. Using the alternative Sias measure we find strong evidence of industry herding by mutual funds. As an additional test we use simulations to show that industry herding by mutual funds is significantly greater than that is expected by chance.

We also examine whether investors' fund flows drive industry herding and find evidence of industry herding even after controlling for fund flows. Our findings also indicate that the reported industry herding is neither a manifestation of individual stock herding nor is it driven by style investing. We report slightly higher levels of industry herding during the internet bubble and bust period and find weak evidence of higher sell herding after high investor sentiment periods. We also explore the effect of industry conditions on industry herding and find evidence that industries with high past industry returns and high volatility levels experience higher levels of buy herding by mutual funds in the subsequent period.

In line with the previous studies, we also examine whether industry herding by mutual funds affects industry returns. We find strong positive contemporaneous relationship between industry herding by mutual funds and industry returns. Industries that are subjected to buy herding by mutual funds outperform industries that are subjected to sell herding in the herding quarter(s). We find no evidence of return reversals for these industries in the periods following the herding, thus concluding that mutual fund herding in industries does not drive industry values away from their fundamentals.

Finally, we document that industry momentum, which is first documented by Moskowitz and Grinblatt (1999) and analyzed extensively in the follow-up studies, is closely related to herding of mutual funds in industries. Specifically, we provide evidence that industry momentum profits, over the first six months of the year after formation of winner and loser industry portfolios, are strongly positively related to the level of herding experience by industries during the formation period. Importantly, the industry momentum portfolio return difference between low- and highherding industries can be completely attributed to the overperformance of winner industries that are subjected to high levels of herding. We further show that high herding winner industries do not experience reversals in the subsequent periods providing evidence for the notion that herding shortens the duration of the underreaction period to good news, but does not result in the destabilization of prices.

This paper makes contribution to two strands of literature. First it compliments the recent herding literature by documenting evidence of industry herding by mutual funds. Our results are robust to investor fund flows, are not motivated by individual stock herding and are also not driven by chance. Second, we add to the extant literature on momentum. Moskowitz and Grinblatt (1999) report that past winner industries outperform past loser industries in the subsequent six to twelve month holding period. We show that industry momentum is related to industry herding by mutual funds.

The remainder of the paper is organized as follows. Section 2 describes the data. Section 3 explains the methodology. Sections 4-6 present the empirical evidence and discuss the results. Section 7 includes our concluding remarks.

\section{Data}

To compute industry herding measures we merge the Thomson-Reuters Mutual Fund Holdings database with the monthly stock files of CRSP. The Thomson-Reuters Mutual Fund Holdings database is merged with the CRSP Mutual Fund database using MFLINIKS database.

Our sample consists of all funds in Thomson-Reuters Mutual Fund Holdings database excluding all international funds and non-equity funds over the $1980-2013$ period. We use ThomsonReuters classification to identify funds' investment objectives. Thomson-Reuters classification for investment objectives are as follows: 1-International, 2-aggressive growth, 3-growth, 4growth-income, 5-municipal bonds, 6-bond and preferred, 7-balanced, 8-metals and 9-unclassified. To focus on actively managed diversified equity funds we only include funds with investment objective classification codes 2, 3 and 4 and also exclude all index and sector funds. ${ }^{7}$ We use CRSP Mutual Funds Database fund style 
Table 1

Descriptive statistics of the mutual fund holdings database.

\begin{tabular}{|c|c|c|c|c|c|c|c|}
\hline Year & 1980 & 1985 & 1990 & 1995 & 2000 & 2005 & 2010 \\
\hline \multicolumn{8}{|l|}{ Panel A. Number and assets of mutual funds } \\
\hline Number of mutual funds & 423 & 496 & 797 & 2235 & 2423 & 1820 & 1377 \\
\hline Mean TNA (in million \$) & 123,467 & 236,812 & 263,423 & 538,967 & $1,290,868$ & $1,872,231$ & $2,522,763$ \\
\hline Median TNA ( in million \$) & 38,100 & 84,110 & 70,320 & 99,630 & 222,130 & 382,285 & 419,290 \\
\hline \multicolumn{8}{|l|}{ Panel B. Asset allocation of mutual funds } \\
\hline Mean ratio of CRSP stocks by value & $83.507 \%$ & $83.343 \%$ & $78.997 \%$ & $78.788 \%$ & $81.673 \%$ & $81.671 \%$ & $78.966 \%$ \\
\hline Median ratio of CRSP stocks by value & $87.429 \%$ & $86.345 \%$ & $83.798 \%$ & $89.277 \%$ & $93.795 \%$ & $92.026 \%$ & $86.461 \%$ \\
\hline
\end{tabular}

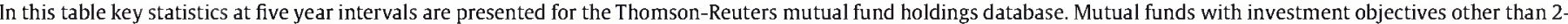

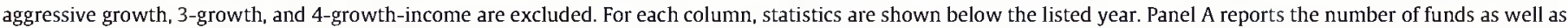

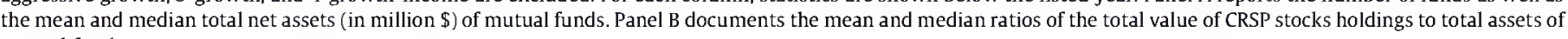
mutual funds.

codes to identify index and sector funds. Panel A of Table 1 presents the number of funds as well as the mean and median assets of mutual funds over the sample period (1980-2013).

Thomson-Reuters provide mutual fund holdings and the date for which these holdings are valid (report date, RDATE). For most funds the holdings information is available at the end of each quarter on this database. However, for some funds there are quarters for which this information is missing. In this paper, we include observations with adjacent fund-stock-quarter observations.

Another complication with the Thomson-Reuters Mutual Holdings database is that there are fund holdings data for a date prior to the end-of-quarter. We consider such reports to be as of the end of the respective quarter following Wermers (1999). In addition, for occasional cases where there are more than one report dates per quarter, we only include the observations with the latest report date. Stock information such as prices, SIC codes, cumulative factors to adjust shares outstanding and returns are obtained from CRSP monthly stock database and matched with mutual fund database. Fund-stock observations which cannot be matched with the CRSP are omitted. ${ }^{8}$ This does not constitute a major problem since the stocks which are not in the CRSP database are usually very small, and are therefore not likely to be widely held by mutual funds. Panel $B$ of Table 1, presents the average and median ratios of the total value of CRSP stocks holdings to total assets of mutual funds for various years during the sample period. As can be seen from this panel, CRSP stocks constitutes significant portion of total assets of mutual funds. Industries are classified in this paper by using Fama and French (1997) 49 Industry specification. ${ }^{9}$

\section{Methodology}

In this section we review the application of the two herding measures that are proposed by LSV (1992) and Sias (2004) to the industries. We also present the buy and sell conditional LSV herding measures proposed by Wermers (1999).

\subsection{The LSV herding measure}

One of the main objectives of this study is to examine whether mutual funds herd in and out of industries. In this sub-section, we apply the LSV herding measure to industries to evaluate industry herding. We start by computing the dollar amount of quarterly change of each mutual fund's holdings in each industry (dolch) as in Choi and Sias (2009). dolch $_{j, k, t}=\sum_{i=1}^{N}\left(\right.$ price $\left._{i, t-1}\right)\left(\right.$ holdings $_{i, j, t}-$ holdings $\left._{i, j t-1}\right)$,

where $N$ is the number of stocks held by mutual fund $j$ over quarter $t-1$ to $t$ and belong to industry $k$, holdings $s_{i j, t}$ is the number of shares of stock $i$ owned by mutual fund $j$ at the end of quarter $t$ adjusted for stock splits, and price $e_{i, t-1}$ is the per-share price of the stock $i$ at the end of quarter $t-1 .{ }^{10}$ Because of changes in stock prices, a mutual fund's dollar holding in an industry might increase or decrease even when the fund does not trade stocks in that industry. To eliminate the effect of stock price changes on the dollar amount of change (dolch), we use the previous quarter-end prices and the change in the number of shares to compute dollar amount of change. We next define mutual fund $k$ as a buyer (seller) in industry $j$ during quarter $t$ if dolch $_{i, j, k}>0\left(\right.$ dolch $\left._{i, j, k}<0\right)$. Using this definition we then compute the ratio of number of buyers to total number of buyers and sellers in industry $k$ during quarter $t$ as

$p_{k, t}=\frac{B_{k, t}}{\left(B_{k, t}+S_{k, t}\right)}$,

where $B_{k, t}\left(S_{k, t}\right)$ is the number of mutual funds that are buyers (seller) in the industry $k$ in quarter $t$. This ratio is referred to as mutual fund demand. ${ }^{11}$ Finally, the LSV herding measure, for industry $k$ and quarter $t, H M_{k, l}$, is computed as

$H M_{k, t}=\left|p_{k, t}-p_{t}\right|-A F_{k, t}$,

where $p_{t}$ is the cross-sectional average of the fraction of buyers (across all industries) in quarter $t . A F_{k, t}$ is an adjustment factor as defined in LSV (1992). ${ }^{12}$

It should be noted that the LSV herding measure in Eq. (3) measures the imbalance in the number of mutual funds that are buyers and sellers in industries without distinguishing whether the imbalance is on the buy or on the sell side. Such distinction is proposed by Wermers (1999) who extends LSV's measure to define buy and sell herding measures as 
$H M_{k, t}^{\text {buy }}=H M_{k, t} \mid\left(p_{k, t}-p_{t}\right)>0$

$H M_{k, t}^{\text {sell }}=H M_{k, t} \mid\left(p_{k, t}-p_{t}\right)<0$.

\subsection{The Sias herding measure}

The LSV herding measure as defined in Eq. (3) detects herding only when the number of investors (from a specific group) that trade in the same direction exceeds what is expected during the same time period. Sias (2004) proposes an alternative herding measure that quantifies the degree to which investors follow trades of other investors (in the same group) in consecutive periods. The Sias herding measure is defined as

$\rho\left(p_{k, t}, p_{k, t-1}\right)=\left[\frac{1}{(K-1) \sigma\left(p_{k, t}\right) \sigma\left(p_{k, t-1}\right)}\right] \sum_{k=1}^{K}\left(p_{k, t}-p_{t}\right)\left(p_{k, t-1}-p_{t-1}\right)$,

where $\rho\left(p_{k, t}, p_{k, t-1}\right)$ is the cross-sectional correlation between ratios of buyers to all traders (mutual fund demand) in consecutive quarters, $K$ is the number of industries, $\sigma\left(p_{k, t}\right)$ is the standard deviation of number of buyers to all traders ratio across industries at time $t$, and $p_{k, t}$ is computed as in Eq. (2). We will observe a positive cross-sectional correlation (Eq. (6)) if funds follow other funds' previous quarter trades or if they repeat their previous quarter trades. The latter case obviously cannot be considered herding and thus its influence should be discarded. ${ }^{13}$ For this reason, Sias (2004) segregates the cross-sectional correlation into two parts:

$$
\begin{aligned}
\rho\left(p_{k, t}, p_{k, t-1}\right)= & {\left[\frac{1}{(K-1) \sigma\left(p_{k, t}\right) \sigma\left(p_{k, t-1}\right)}\right] \sum_{k=1}^{K}\left[\sum_{n=1}^{N_{k, t}}\left(\frac{D_{n, k, t}-p_{t}}{N_{k, t}} \cdot \frac{D_{n, k, t-1}-p_{t-1}}{N_{k, t-1}}\right)\right] } \\
& +\left[\frac{1}{(K-1) \sigma\left(p_{k, t}\right) \sigma\left(p_{k, t-1}\right)}\right] \sum_{k=1}^{K}\left[\sum_{n=1}^{N_{k, t}} \sum_{m=1, m \neq n}^{N_{k, t-1}}\left(\frac{D_{n, k, t}-p_{t}}{N_{k, t}} \cdot \frac{D_{m, k, t-1}-p_{t-1}}{N_{k, t-1}}\right)\right] .
\end{aligned}
$$

The first term on the right hand side of the Eq. (7) is the contribution to the cross-sectional correlation of funds following their own trades in the previous quarter while the second term is the contribution of funds following other funds' trades in the previous quarter. $D_{n, k t}$ is a dummy variable that takes the value of $1(0)$ if fund $n$ buys (sells) industry $k$ in quarter $t, N_{k, t}$ is the number of mutual funds trading industry $k$ in quarter $t$.

\section{Evidence of industry herding by mutual funds}

This section reports the empirical evidence of industry herding by mutual funds using the previously established industry herding measures (Eqs. (3), (4), (5) and (7)) and are estimated over the 1980-2013 period and by employing the FF 49-industry classification. We first report the statistical outcome of this investigation and then present Monte Carlo simulation results that contrast the distribution of the LSV and Sias herding measures as compared to those implied by a no-herding null hypothesis. We then examine herding by funds with different investment objectives and whether investor flows drive industry herding. We explore whether industry herding is a manifestation of individual stock herding and whether it is driven by style investing. We also report industry herding by mutual funds in different time periods and during high and low investor sentiment periods. Lastly, we investigate whether the industry conditions affect mutual fund industry herding.

\subsection{Industry herding - the evidence}

Previous studies propose several theories that explain why institutional managers may herd at the individual stock level or at the industry level. Institutional managers may herd if they receive correlated signals and trade on these signals (investigative herding; Froot et al., 1992; Hirshleifer et al., 1994), infer information from the prior trades of other managers and follow their trades (informational cascades; Bikhchandani et al., 1992; Welch, 1992), follow other managers due to reputational concerns (reputational herding; Scharfstein and Stein, 1990; Zwiebel, 1995), or follow the fads (Friedman, 1984). Furthermore, empirical evidence presented in the literature indicates that mutual fund managers engage in certain behavioral patterns that might result in herding. Specifically, Brown et al. (2014) show that mutual fund managers trade on the same new information, Friend et al. (1970) report that mutual fund managers mimic the trades of other funds with good performance, Chevalier and Ellison (1999) present evidence that mutual fund managers trade due to reputational concerns, and Falkenstein (1996) documents that mutual funds tend to chase certain characteristics. These theoretical and empirical studies indicate the possibility that the mutual funds herd in industries. We test the following hypothesis by employing both LSV and Sias herding measures.

H1. Mutual funds herd in industries. ${ }^{14}$

\subsubsection{LSV herding measure- the evidence}

Table 2 displays the mean and median levels for the LSV herding measure (HM) and the Wermers' (1999) buy herding measure (BHM) and sell herding measure (SHM). Following Wermers (1999) the results are presented for industry-quarters traded by at least 5, 20 and 50 mutual funds. The three respective mean values for the industry herding measure (HM) as reported in Panel A are $1.599 \%, 1.557 \%$, and $1.529 \%$, all are significant at the $1 \%$ level. These figures are in line with Choi and Sias' (2009) findings for all institutions and are slightly higher than that reported by LSV (1992) for pension funds. Panel A also presents the corresponding median values. All medians are also statistically significantly at the $1 \%$ level and are considerably lower than their respective means, signifying right-skewness of this herding measure. ${ }^{15}$ Panel B presents the mean and median values for buy and sell herding for the industry-quarters traded by at least 5,20 , and 50 mutual funds respectively. As can be seen from this panel, the sell herding figures are slightly greater than the buy herding figures, but not significantly so for the industry-quarters where there are at least 50 active mutual funds. ${ }^{16}$

The observed overall mean herding levels, though statistically significant, are not high. As indicated by Table 2 for the case where there are at least 50 active mutual funds on average $1.529 \%$ more mutual funds trade industries in the same direction than what is expected.

\subsubsection{Sias herding measure - the evidence}

In this sub-section we examine whether mutual funds herd in industries using the Sias herding measure as defined in Eq. (7). This 
Table 2

Evidence of herding-LSV measure.

\begin{tabular}{|c|c|c|c|}
\hline & At least 5 active mutual funds & At least 20 active mutual funds & At least 50 active mutual funds \\
\hline \multicolumn{4}{|c|}{ Panel A. Herding measure } \\
\hline Mean & 0.01599 & 0.01557 & 0.01529 \\
\hline t-Stat & $(29.83)$ & $(30.66)$ & $(31.97)$ \\
\hline Median & 0.00827 & 0.00820 & 0.00827 \\
\hline \multicolumn{4}{|c|}{ Panel B. Buy and sell herding measures } \\
\hline \multicolumn{4}{|c|}{ Buy herding measure } \\
\hline Mean & 0.01491 & 0.01442 & 0.01475 \\
\hline t-Stat & $(19.51)$ & $(19.84)$ & $(21.15)$ \\
\hline Median & 0.00760 & 0.00743 & 0.00769 \\
\hline \multicolumn{4}{|c|}{ Sell herding measure } \\
\hline Mean & 0.01700 & 0.01663 & 0.01579 \\
\hline t-Stat & $(22.62)$ & $(23.45)$ & $(24.04)$ \\
\hline Median & 0.00874 & 0.00879 & 0.00864 \\
\hline
\end{tabular}

This table presents mean and median values of the LSV herding measures (unconditional, buy, and sell) for industry quarters where there are at least 5,20 and 50 active mutual funds during the 1980-2013 period. The LSV herding measure, $H M_{k, t}$ for each industry-quarter is defined as $H M_{k t}=\left|p_{k, t}-p_{t}\right|-A F_{k t}$ where $p_{k, t}$ is the ratio of number of buyers to total number of mutual funds that are either buyers or sellers, $p_{t}$ is the cross-sectional average of fraction of buyers (across $K$ industries) in quarter $t$, and $A F_{k t}$ is an adjustment factor that accounts for the fact that even in the case of no herding $\left|p_{k, t}-p_{t}\right|$ can be greater than zero (by chance or an odd number of traders). The buy herding measure is computed by conditioning $H M_{k t}$ on ( $\left.p_{k t}-p_{t}\right)>0$, and the sell herding measure is computed by conditioning $H M_{k r}$ on $\left(p_{k, t}-p_{t}\right)<0$. All stocks that have price information in the CRSP database are included. All sector and index funds are excluded. Industries are classified by using Fama and French 49 Industry specification. $T$-statistics are reported in parenthesis.

measure is the average cross-sectional correlation of fraction of buyers to all traders between all pairs of consecutive quarters. However, we are primarily interested in the contribution of funds following other mutual funds' industry trades to this cross-sectional correlation (second term on the right hand side of Eq. (7)). Table 3, Panel A presents the average and median values and the corresponding Newey-West adjusted $t$-statistics of the cross-correlations (Newey and West, 1987). The mean values of the crosssectional correlation are $23.090 \%, 24.096 \%$, and $28.935 \%$ for the cases where there are at least 5,20 , and 50 active mutual funds, respectively. These figures are slightly lower than what Choi and Sias (2009) find for all institutions, but are still quite high and statistically significant at the $1 \%$ level. The median values for the cross-sectional correlations are very close to the mean levels. Panel $B$ of this table reports the component of cross-sectional correlation that arises from funds following their own industry trades (first term in Eq. (7)), while Panel C presents the component that arises from funds following other funds' industry trades (second term in Eq. (7)). As can be seen from this table the contribution of funds following other funds constitutes a significant portion of the total cross-sectional correlation.

We next segregate the total cross-sectional correlation and its two components into two parts, namely the contribution of buy herding and contribution of sell herding. The contributions of buy and sell herding to the total cross-sectional correlation and to its two components are computed by taking into account those previous quarter mutual fund demand figures in excess of (for buy herding) or less than (for sell herding) 0.5. Panels D, E, and F of Table 3 present the contribution of buy and sell herding to the total cross-sectional correlation, the contribution of mutual funds following their own industry trades, and the contribution of mutual funds following other funds' industry trades, respectively. As for other panels of this table, the results are reported for the industry-quarters where there are at least 5, 20, and 50 active mutual funds. As can be seen from these panels the contribution of buy and sell herding to the total cross-sectional correlation and its two components are similar to each other. We also conduct tests and find that contributions of buy and sell herding are not significantly different from each other.

To sum up, the results presented in this sub-section are in support of hypothesis 1 and provide strong evidence of industry herding by mutual funds in the Sias herding framework, that is, mutual funds follow other mutual funds' previous quarter industry trades.

\subsection{Simulation results vs. actual data}

In this sub-section, as an additional test for the existence of industry herding by mutual funds, we run Monte Carlo simulations to examine whether the actual distributions of the LSV and Sias herding measures are different from those we would observe if no herding takes place. To generate the simulated distributions of the two herding measures, we follow a similar procedure to that employed by Wermers (1999). The number of mutual funds that are buyers in industry $k$ in quarter $t$ is modeled as a binomial distribution, $b\left(n_{k, t}, p_{t}\right)$ where $n_{k, t}$ is the actual total number of mutual funds that are either buyers or sellers in industry $k$ in quarter $t$ $\left(B_{k, t}+S_{k, t}\right)$, and $p_{t}$ is the actual cross-sectional average of the fraction of buyers (across all industries) in quarter $t$. For each industry-quarter, we draw a random number between 0 and 1 , round it to 0 if the random draw is less than $1-p_{t}$ and round it to 1 otherwise. 0 indicates that fund is a seller while 1 indicates that fund is a buyer. This step is repeated $n_{k t}$ times to give a draw from binomial distribution, $b\left(n_{k, t}, p_{t}\right)$. We then repeat these steps for each industry-quarter. Using the drawn number of buyers and sellers, we compute the simulated fraction of buyers to all traders, $p_{k, t}$ for each industry-quarter and the simulated cross-sectional average of the fraction of buyers, $p_{t}{ }^{*}$ (across $K$ industries), for each quarter. We use the simulated fraction of buyers $p_{k, t}{ }^{*}$ and the simulated cross-sectional average of fraction of buyers, $p_{t}^{*}$ to compute the simulated LSV (HMsim) and the simulated Sias $\left(\rho\left(p_{k}{ }^{*}, p_{k, t-1}{ }^{*}\right)\right)$ herding measures. We repeat this procedure to generate 1000 simulated industry-quarter observations for each actual industryquarter observation.

Panel A of Fig. 1 presents the simulated and actual distributions of the LSV herding measure. As can be seen from this figure the actual distribution of this measure has fatter right tail than the simulated one, indicating that mutual funds engage in herding behavior in industries beyond the level that is expected by random chance. Fig. 1, Panel B shows the actual and the simulated distributions of the Sias herding measure. The actual distribution lies to the right of the simulated distribution, which is consistent with actual 
Table 3

Evidence of herding-Sias measure.

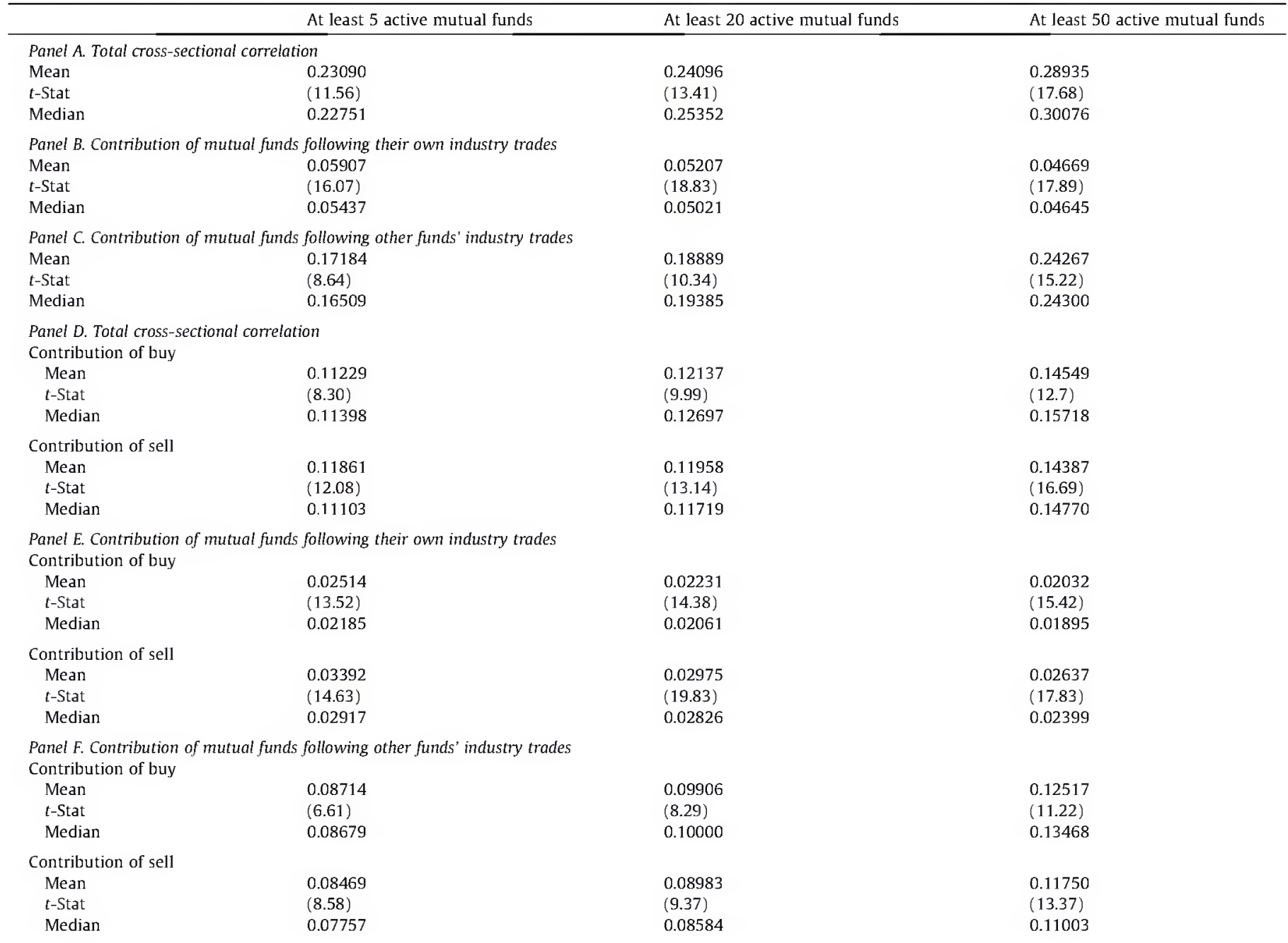

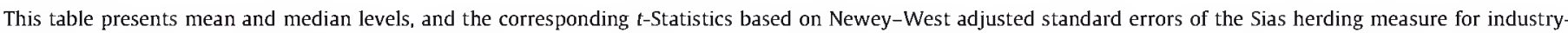

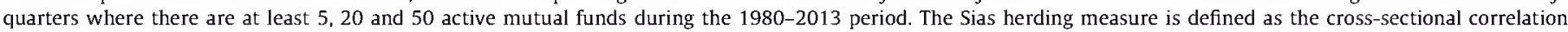

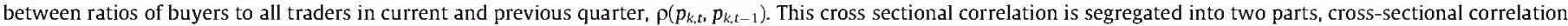

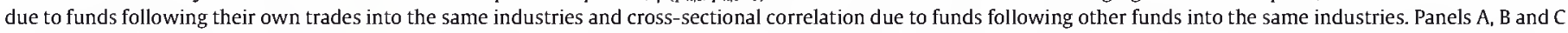

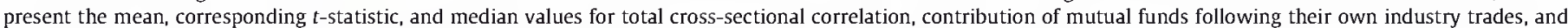

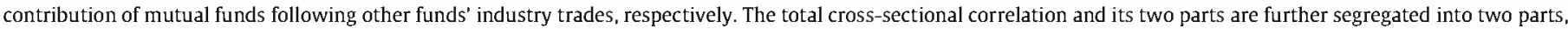

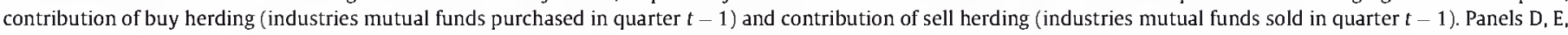

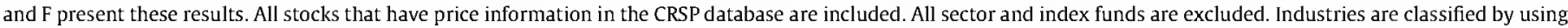
Fama and French 49 Industry specification.

cross-sectional correlations being much higher than what we may observe by random chance alone. We employ the KolgomorovSmirnov two-sample test and find that the actual sample distributions of the LSV and Sias herding measures are statistically different from their corresponding simulated distributions at the $1 \%$ significance level. ${ }^{17}$ These results provide evidence of mutual fund herding in industries.

\subsection{Industry herding and investment objectives}

As discussed in Section 2 our sample includes mutual funds with "aggressive-growth", "growth" and "growth-income" investment objectives. In order to examine whether these different types of mutual funds exhibit differences in their herding behavior, in this sub-section we compute average herding levels separately for these different types of funds. There is evidence of industry herding within each of the three mutual fund investment objective categories. For example, for industry-quarters for which there are at least five active traders the mean LSV measures for the aggressive-growth, growth and growth-income funds are $1.044 \%$, $1.174 \%$, and $1.185 \%$, respectively; all of them are statistically significant at the $1 \%$ level and these means are not significantly different from each other. ${ }^{18}$ Funds with aggressive-growth investment objective exhibit significantly lower levels of buy herding LSV measure as compared to the two other types of funds. Mean sell herding LSV measure for aggressive-growth mutual funds is slightly higher than that of growth and growth-income mutual funds. Furthermore, the differences between mean herding levels (unconditional, buy, and sell) using LSV measure exhibited by growth and growth-income funds are not statistically significant. Using the Sias measure, we report that the mean total cross sectional correlation for the 
Panel A. Distributions of the Simulated and Actual LSV Herding Measure
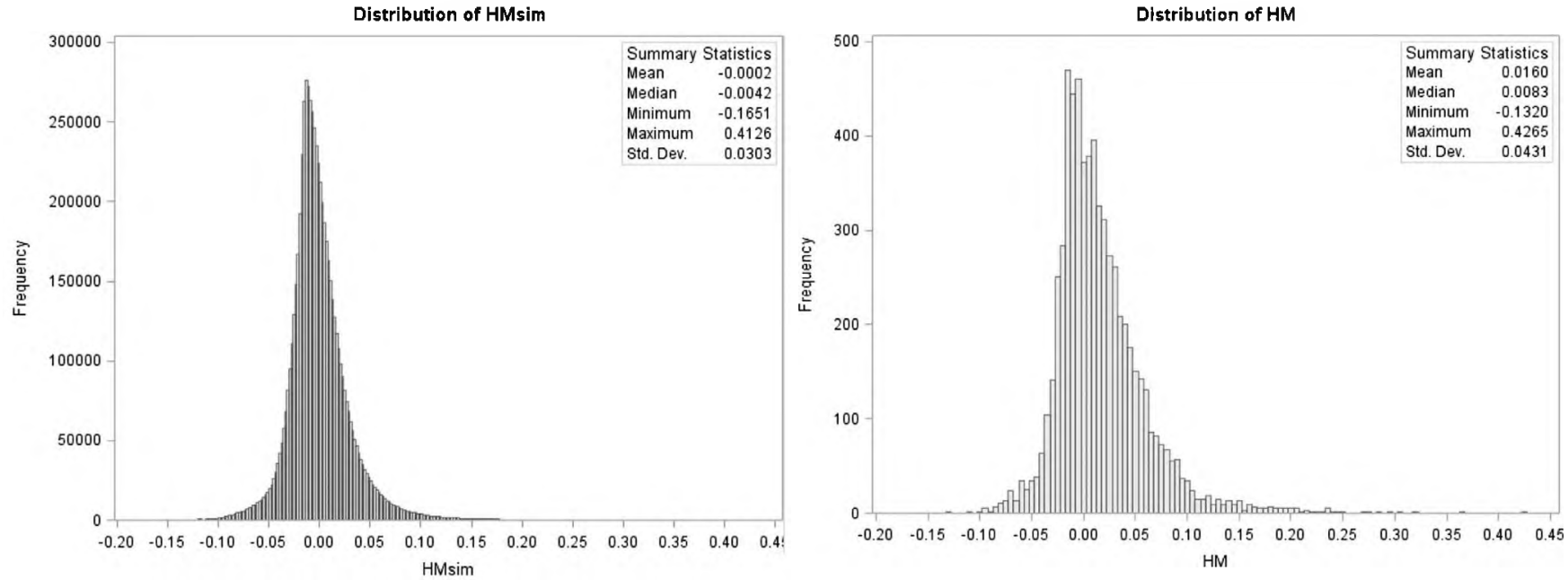

Panel B. Distributions of the Actual and Simulated Sias Herding Measure
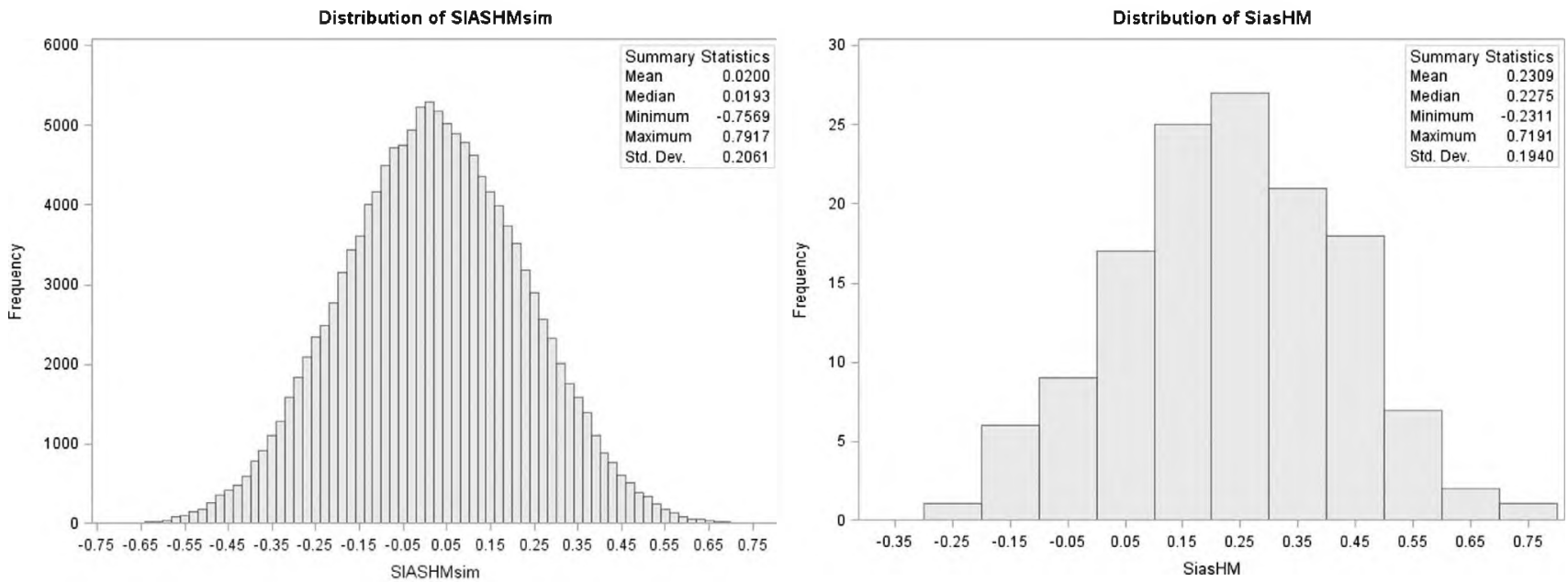

Fig. 1. Distributions of actual and simulated herding measures. The number of mutual funds that are buyers in industry $k$ in quarter $t$, is modeled as a binomial distribution, $b\left(n_{k+t} p_{t}\right)$ where $n_{k, t}$ is the actual total number of mutual funds that are either buyers or sellers in industry $k$ in quarter $t\left(B_{k t}+S_{k t}\right)$, and $p_{t}$ is the actual cross-sectional average of fraction of buyers (across $K$ industries) in quarter $t$. First, for each industry-quarter, a random number between 0 and 1 is drawn, and is rounded to 0 if the random draw is less than $1-p_{t}$ and rounded to 1 atherwise. This step is repeated $n_{k, t}$ times and then for each industry-quarter. Then, using the simulated number of buyers and sellers, the simulated fraction of buyers, $p_{k}^{*}$, and the simulated cross-sectional average of fraction of buyers, $p_{i}^{*}$ (across $K$ industries) are computed in quarter $t$. Finally, the simulated LSV herding measure, $H M \operatorname{sim}_{k t}$ is computed for each industry-quarter as HMsim ${ }_{k, t}=\left|p_{k, t}^{*}-p_{t}^{*}\right|-A F_{k t}$. Actual LSV herding measure HM, as described in Table 2, is also calculated for our sample. For each adjacent quarters, simulated Sias measure (SiasHmsim), $\rho\left(p_{k,}^{*}, p_{k,-1}^{*}\right.$ ), the cross-sectional correlation between ratios of simulated number of buyers to all traders in current and previous quarter, is also computed. This procedure is repeated to generate 1000 simulated industry-quarter observations for each actual industryquarter observation. Actual Sias measure (SiasHM) $\rho\left(p_{k, t}, p_{k, t-1}\right)$ as described in Table 3 , is also calculated for our sample. Panel A presents the simulated and actual distribution of the LSV herding measure (HMsim $\left.k_{k, t} H M_{k, t}\right)$. Panel B presents the simulated Sias herding measure (SiasHMsim), $\rho\left(p_{k, t}^{*}, p_{k, t-1}{ }^{*}\right)$ and actual distribution of the Sias herding measure, $\rho\left(p_{k, t}, p_{k, t-1}\right)$.

aggressive-growth, growth and growth-income funds are $11.00 \%$, $15.84 \%$, and $13.57 \%$, respectively and all three are statistically significant at the $1 \%$ level. There is no significant difference between the herding levels according to Sias herding measure among the three types of mutual funds.

\subsection{Is industry herding driven by fund flows?}

In this sub-section we examine whether the evidence of industry herding that is presented in the preceding sub-sections is driven by fund flows. Coval and Stafford (2007) show that mutual funds buy more of the stocks that they already hold when they experience cash inflows. Likewise, mutual funds have to sell their holdings when they suffer excessive cash outflows. If cash inflows and/or outflows are concentrated on funds that have similar industry allocations, even in the absence of any herding behavior, flows might induce funds to trade in the same direction and cause imbalance between the proportion of number of buyers and sellers. Similarly if these investor flows persist over several quarters they might result in positive cross-sectional correlation between mutual fund demands in consecutive quarters. Therefore, we need to ensure that our reported herding behavior is not driven by fund inflows and outflows and hence we test the following hypothesis:

H2. Mutual fund industry herding is not driven by fund flows.

To control for the effect of flows on industry herding measures, we require a fund to change its portfolio weight in an industry in the same direction with its trade to be classified as an active trader for that industry-quarter. 
Table 4

Herding levels after controlling for fund flows.

\begin{tabular}{|c|c|c|c|c|}
\hline & & At least 5 active mutual funds & At least 20 active mutual funds & At least 50 active mutual funds \\
\hline \multicolumn{5}{|c|}{ Panel A. LSV herding measure } \\
\hline \multicolumn{5}{|c|}{ Herding measure } \\
\hline Mean & & 0.03612 & 0.03620 & 0.03739 \\
\hline t-Stat & & $(48.43)$ & $(49.72)$ & $(50.58)$ \\
\hline Median & & 0.02424 & 0.02439 & 0.02542 \\
\hline \multicolumn{5}{|c|}{ Buy herding measure } \\
\hline Mean & & 0.03377 & 0.03404 & 0.03562 \\
\hline$t$-Stat & & $(33.8)$ & $(34.59)$ & $(35.69)$ \\
\hline Median & & 0.02295 & 0.02302 & 0.02436 \\
\hline \multicolumn{5}{|c|}{ Sell herding measure } \\
\hline Mean & & 0.03857 & 0.03846 & 0.03926 \\
\hline$t$-Stat & & $(34.75)$ & $(35.77)$ & $(35.89)$ \\
\hline Median & & 0.02560 & 0.02591 & 0.02655 \\
\hline \multicolumn{5}{|c|}{ Panel B. Sias herding measure } \\
\hline Mean & Mutual funds following their own trades & 0.02851 & 0.02170 & 0.01768 \\
\hline t-Stat & & $(7.84)$ & $(8.4)$ & $(6.96)$ \\
\hline Median & & 0.02053 & 0.01789 & 0.01504 \\
\hline Mean & Mutual funds following other funds' trades & 0.10999 & 0.11205 & 0.13827 \\
\hline t-Stat & & $(4.8)$ & $(4.77)$ & $(5.59)$ \\
\hline Median & & 0.13139 & 0.13026 & 0.13579 \\
\hline Mean & Total cross-sectional correlation & 0.13849 & 0.13375 & 0.15594 \\
\hline t-Stat & & $(5.60)$ & $(5.52)$ & $(6.01)$ \\
\hline Median & & 0.15517 & 0.15757 & 0.15395 \\
\hline
\end{tabular}

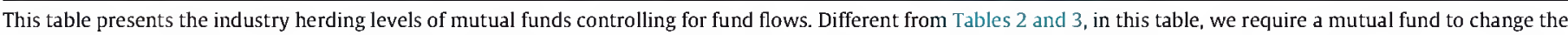

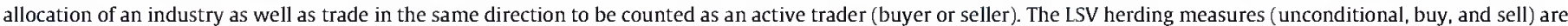

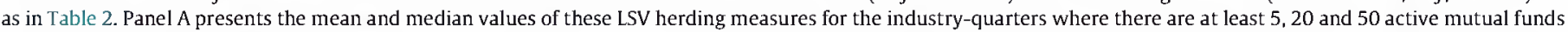

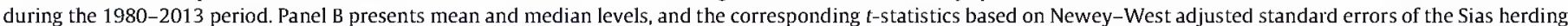

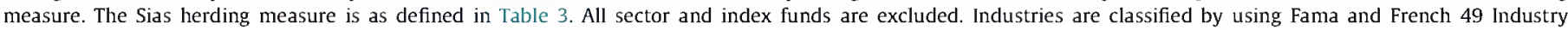
specification.

Panels A and B of Table 4 present the mean and median herding levels of the LSV and Sias measures, respectively after controlling for fund flows. As can be seen from Panel A of this table the respective mean LSV herding measures are $3.612 \%, 3.620 \%$, and $3.739 \%$ (significant at the 1\% level) for the industry-quarters where there are at least five, twenty, and fifty active mutual funds, respectively. The mean and median values for the buy and sell herding are also reported in this panel. These figures are considerably higher than those reported in Table 2 . In contrast, we observe that controlling for fund flows decreases the observed Sias measures as reported in Panel B. The corresponding mean Sias measures are $13.849 \%$, $13.375 \%$, and $15.594 \%$ for the three different filters of number of active mutual funds. However, these figures are still significant at the $1 \%$ level. The contribution of funds following other funds continues to be a significant portion of total cross-sectional correlation. In sum, these results reveal that industry herding is not driven by fund flows and support hypothesis 2 .

\subsection{Is industry herding driven by individual stock herding?}

The preceding subsections provide evidence of mutual fund herding in industries. In this subsection, we examine whether this observed industry herding is a manifestation of individual stock herding that is reported in the literature (e.g. Wermers, 1999; GTW, 1995). Choi and Sias (2009) provide evidence that institutional industry herding is not a manifestation of individual stock herding. We hypothesize that even in the presence of individual stock herding mutual funds might herd at the industry level. We test the following hypothesis:

H3. Mutual fund industry herding is not a manifestation of individual stock herding.

To test this hypothesis in the LSV framework we repeat the analysis performed in Section 4.1.1 after excluding the stock with the highest level of herding for each industry-quarter. The rationale for this filter is that, if we still find evidence of industry herding even when the contribution of highest herded stock is not taken into account then the observed industry herding cannot be a manifestation of individual stock herding. We find that after excluding the stock with the highest herding level in each-industry quarter, the mean LSV herding measure is $1.0827 \%$ and statistically significant at the $1 \%$ level for the industry-quarters where there are at least 50 active mutual funds.

To examine the same question in the Sias framework we follow Choi and Sias' (2009) methodology. Choi and Sias (2009) first define the ratio of buyers to all traders for an industry-quarter as the weighted average of this ratio for individual stocks belonging to the same industry where the previous quarter-end market value is used to compute the weights. They then decompose the crosssectional correlation of the current and previous quarter weighted ratio of number of buyers to all traders into four components: the contribution of funds following their own stock trades, contribution of funds following other funds' individual stock trades, contribution of funds following themselves into other stocks in the same industry and contribution of funds following other funds into other stocks in the same industry. We need to focus on the fourth component of cross-sectional correlation. For our sample, the mean values for the first, second, third, and fourth components are $4.89 \%, 16.69 \%, 5.02 \%$, and $6.05 \%$, respectively. ${ }^{19}$ The total cross-sectional correlation is $32.66 \%$. All these figures are statistically significant at the $1 \%$ level. ${ }^{20}$. These results indicate that while the significant portion of the cross-sectional correlation arises due to funds following other funds into the same stock, a nontrivial portion arises due to funds following other funds into different stocks in the same industry. 
To sum, the findings in this sub-section reveal that although individual stock herding contributes to the industry herding that we observe, industry herding is not a manifestation of individual stock herding supporting our hypothesis 3 .

\subsection{Is industry herding driven by style investing?}

In this sub-section we explore the contribution of style investing to the industry herding by mutual funds. Style investing can contribute to industry herding due to the following two main reasons. First, many industries are comprised of stocks with similar characteristics in terms of market capitalizations (size) and bookto-market ratios $(\mathrm{B} / \mathrm{M}){ }^{21}$ Funds may invest in the same industries as a result of their other style-strategies, such as size and B/M. Second, as Choi and Sias (2009) suggest, industry related information that managers receive might also have size-B/M components. As a result the observed industry herding by mutual funds may be mainly driven by mutual fund herding in different stocks with similar size$\mathrm{B} / \mathrm{M}$ styles within the same industry.

To examine the extent to which style investing contributes to industry herding by mutual funds we follow a similar methodology to that of Choi and Sias (2009). We first group stocks into six styles based on size and B/M, two size groups based on median NYSE size, and three groups based on $\mathrm{B} / \mathrm{M}$ ratios using the 30th and 70th percentile as the cut off values. ${ }^{22}$ We then segregate the contribution of funds following other funds into other stocks in the same industry (fourth component of total cross sectional correlation from Section 4.5) into two: (1) different stocks in the same industry and in the same style group and (2) different stocks in the same industry but in different style groups. We also compute the expected contribution of these two components to this fourth component of total cross sectional correlation. ${ }^{23}$ We find that the average contributions of components (1) and (2) are $2.67 \%$ and $3.37 \%$, respectively, and both are significant at the $1 \%$ level. ${ }^{24}$ The expected contributions of (1) and (2) are $2.25 \%$ and $3.80 \%$, respectively. The difference between the expected and the actual values of components (1) and (2) are $0.43 \%$ and $-0.43 \%$, and these differences are not significantly different from zero. These findings suggest that industry herding is not mainly driven by style investing.

\subsection{Industry herding by mutual funds in different time periods}

In this sub-section we examine industry herding by mutual funds over different time periods. Following Choi and Sias (2009), first, we split our sample period into two sub-periods, 19801995, and 1996-2013, to examine whether mutual fund industry herding increased once institutional investors were required to file their holding positions through the Electronic Data Gathering and Retrieval (EDGAR) system after 1996. Second, we divide our sample period into three sub-periods 80s (1980-1989), 90s (19901999), and 2000s (2000-2013) to explore whether there is any change in herding behavior by mutual funds over the three decades. Barras et al. (2010) find that US fund managers' skill levels exhibit signs of deterioration over the years to date. Hence we would expect that the magnitude of industry herding grows stronger over the decades. Third, we examine industry herding over the internet bubble and bust period (1998-2001).

Results of these analyses are reported in Table 5. Panels A and B present the mean and the corresponding $t$-statistics of the LSV and Sias herding measures, respectively for the different time periods. The mean LSV (SIAS) measure for the post-Edgar period (19962013 ) is slightly higher (lower) than that for the pre-Edgar period (1980-1995). However, consistent with the findings of Choi and Sias (2009) we find that these differences are not significantly different from zero. We also find that the average LSV measure, which is $1.629 \%$ during the $90 \mathrm{~s}$, is slightly higher than the average LSV measures during the 80 s and 2000 s, but not significantly so. The average Sias herding measure during the 80 s is slightly higher than the two other sub-periods, but again these differences are not significant at the $5 \%$ level. Therefore, the evidence reported in panels $A$ and $B$ of Table 5, does not indicate that industry herding by mutual funds increased progressively over the decades. We also find that industry herding by mutual funds during the internet bubble and bust period is slightly higher than that over the entire sample period. However, the average Sias herding measures for this period are similar to those for the entire sample period.

\subsection{Investor sentiment and industry herding by mutual funds}

Previous studies, (LSV, 1992; Barberis and Shleifer, 2003; and Shleifer, 2000) suggest that individual investor sentiment might affect institutional herding. A more recent study by Liao et al. (2011) examines whether previous investor sentiment explains the cross-sectional variation in individual stock herding by mutual funds over the 2003-2007 period. They find evidence that mutual funds engage in sell herding in stocks that have prior high sentiment. They conclude that this finding is consistent with the sentiment countering hypothesis which states that rational investors tend to counteract the optimistic sentiment of the retail/noise investors.

In this sub-section, we investigate whether overall market-wide investor sentiment affects industry herding by mutual funds. We employ Baker and Wurgler's (2007) monthly investor sentiment index to identify high and low investor sentiment periods. ${ }^{25}$ This investor sentiment index is constructed based on six sentiment proxies, namely, trading volume, the dividend premium, the closed-end fund discount, the number and first-day returns on IPOs and the equity share in new issues. ${ }^{26}$ As we have quarterly herding measures we first compute quarterly averages of monthly investor sentiment index. We next compute average quarterly investor sentiment over the $1980-2010$ period. ${ }^{27}$ We identify the quarters with investor sentiment higher (lower) than the sample period average as high (low) investor sentiment periods. We then compute mean herding levels separately for the quarters following the high sentiment and low sentiment quarters. Panel A of Table 6 presents the LSV herding measures (unconditional, buy, and sell) after the high and low sentiment quarters as well as the difference between them for the industry-quarters where there are at least 5, 20, and 50 active mutual funds. For the industry-quarters where there are at least 5 active mutual funds, average herding measure is higher after the high investor sentiment periods than that after the low investor 
Table 5

Herding levels in different time periods.

\begin{tabular}{|c|c|c|c|c|c|c|}
\hline & 1980-1995 & 1996-2013 & 1980-1989 & 1990-1999 & 2000-2013 & $1998-2001$ \\
\hline \multicolumn{7}{|c|}{$\begin{array}{l}\text { Panel A. LSV herding measure } \\
\text { Herding measure }\end{array}$} \\
\hline $\begin{array}{l}\text { Mean } \\
\text { t-Stat }\end{array}$ & $\begin{array}{l}0.01459 \\
(18.14)\end{array}$ & $\begin{array}{l}0.01578 \\
(26.93)\end{array}$ & $\begin{array}{l}0.01452 \\
(13.11)\end{array}$ & $\begin{array}{l}0.01629 \\
(18.16)\end{array}$ & $\begin{array}{l}0.01505 \\
(23.54)\end{array}$ & $\begin{array}{l}0.02223 \\
(14.86)\end{array}$ \\
\hline $\begin{array}{c}\text { Buy herd } \\
\text { Mean } \\
t \text {-Stat }\end{array}$ & $\begin{array}{l}0.01418 \\
(12.44)\end{array}$ & $\begin{array}{l}0.01517 \\
(17.37)\end{array}$ & $\begin{array}{l}0.01497 \\
(9.36)\end{array}$ & $\begin{array}{l}0.01451 \\
(11.73)\end{array}$ & $\begin{array}{l}0.01479 \\
(15.18)\end{array}$ & $\begin{array}{l}0.02136 \\
(9.52)\end{array}$ \\
\hline $\begin{array}{c}\text { Sell herd } \\
\text { Mean } \\
\text { t-Stat }\end{array}$ & $\begin{array}{l}0.01499 \\
(13.21)\end{array}$ & $\begin{array}{l}0.01634 \\
(20.71)\end{array}$ & $\begin{array}{l}0.01408 \\
(9.18)\end{array}$ & $\begin{array}{l}0.01790 \\
(13.89)\end{array}$ & $\begin{array}{l}0.01528 \\
(18.20)\end{array}$ & $\begin{array}{l}0.02284 \\
(11.40)\end{array}$ \\
\hline \multicolumn{7}{|c|}{ Panel B. Sias herding measure } \\
\hline $\begin{array}{l}\text { Mean } \\
t \text {-Stat }\end{array}$ & $\begin{array}{l}0.30715 \\
(12.26)\end{array}$ & $\begin{array}{l}0.27403 \\
(13.16)\end{array}$ & $\begin{array}{l}0.33052 \\
(9.24)\end{array}$ & $\begin{array}{l}0.27260 \\
(12.34)\end{array}$ & $\begin{array}{l}0.27339 \\
(10.86)\end{array}$ & $\begin{array}{l}0.30798 \\
(9.56)\end{array}$ \\
\hline $\begin{array}{c}\text { Mutual f } \\
\text { Mean } \\
\text { t-Stat }\end{array}$ & $\begin{array}{l}\text { ig themselves } \\
0.05412 \\
(15.17)\end{array}$ & $\begin{array}{l}0.04028 \\
(14.63)\end{array}$ & $\begin{array}{l}0.05735 \\
(10.87)\end{array}$ & $\begin{array}{l}0.04603 \\
(13.11)\end{array}$ & $\begin{array}{l}0.03992 \\
(13.79)\end{array}$ & $\begin{array}{l}0.03356 \\
(9.49)\end{array}$ \\
\hline $\begin{array}{c}\text { Mutual } f \\
\text { Mean } \\
\text { t-Stat }\end{array}$ & $\begin{array}{c}\text { ig others } \\
0.25302 \\
(10.63)\end{array}$ & $\begin{array}{l}0.23375 \\
(11.06)\end{array}$ & $\begin{array}{l}0.27317 \\
(8.10)\end{array}$ & $\begin{array}{l}0.22657 \\
(9.53)\end{array}$ & $\begin{array}{l}0.23347 \\
(9.31)\end{array}$ & $\begin{array}{l}0.27442 \\
(8.28)\end{array}$ \\
\hline
\end{tabular}

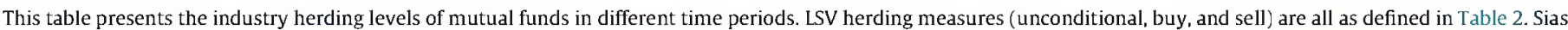

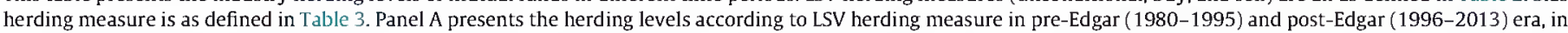

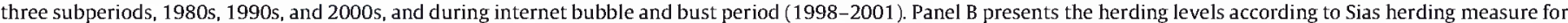
the same time periods. Results are presented in Panel A and B are for the industry-quarters where there are at least 50 active mutual funds.

sentiment period. Furthermore, this difference is mainly due to higher sell herding after high investor sentiment periods. ${ }^{28}$ This evidence is consistent with the findings of Liao et al. (2011) and supports the sentiment countering hypothesis. However, as we filter the industry-quarter observations with less than 20 active traders the difference between the average of sell herding measures after the high and the low investor sentiment periods diminishes and it becomes insignificant after applying 50 active traders filter. This finding suggests that investor sentiment effect on sell herding of mutual funds is more prominent in smaller industries. These industries are more likely to include stocks of relatively lower size for which investor sentiment is more relevant. As these industries are filtered out after applying higher number of active fund thresholds, investor sentiment impact on fund herding fades out.

Panel B of Table 6 reports mean Sias herding measure (total cross-sectional correlation and its two parts) after the high and low sentiment quarters as well as the difference between them for the industry-quarters where there are at least 5,20 , and 50 active mutual funds. We find no meaningful difference between the Sias herding measures after high and low sentiment periods.

To sum up, we find some evidence that mutual funds tend to engage in (same quarter) sell herding in industries more after optimistic sentiment periods, consistent with the sentiment countering hypothesis.

\subsection{Industry conditions and mutual fund industry herding}

In this sub-section we examine whether industry conditions affect industry herding by mutual funds. Specifically, we explore whether previous quarter's industry conditions such as return, volatility, and volume affect industry herding.

We perform similar analysis to that of a recent study by Gavriilidis et al. (2013), which documents evidence that sector and market conditions affect industry herding by Spanish mutua funds. First, we examine the impact of industry returns on mutual fund industry herding. In order to identify high-mid-low return periods for each industry, we rank the quarterly value weighted returns of each industry over our sample period into three groups (high-mid-low industry returns). We compute average subsequent quarter LSV measures separately for these high-mid-low return groups. Panel A of Table 7 presents the mean LSV herding measures (unconditional, buy, and sell) for the high, mid, and low industry return groups. The last column reports the difference between the herding measures for high and low industry return groups. As can be seen from this panel highest (lowest) industry herding is exhibited when the industry returns are high (low). Furthermore, the difference between herding measures in high and low industry return groups is statistically significant at the $1 \%$ level. The results for the buy and sell herding measures indicate that the difference between the (unconditional) herding levels is mainly driven by buy herding. There is no evidence that industry returns affect subsequent quarter sell herding by mutual funds.

Second, we examine the effect of industry volatility on industry herding using a similar analysis. We define quarterly volatility as the standard deviation of daily (value weighted) industry returns for each industry-quarter. In order to identify high-mid-low volatility periods for each industry, we rank the quarterly volatility of each industry over our sample period into three groups. We again compute average subsequent quarter LSV measures separately for these high-mid-low volatility groups. Panel B of Table 7 presents the results of the volatility analysis. Similar to Panel A we report evidence that industry herding is higher after periods of high industry volatility and this difference is mainly driven by the difference in buy herding for these high and low volatility groups. ${ }^{29}$

Lastly, we investigate the impact of industry turnover on industry herding by mutual funds. We divide monthly volume by the number of outstanding shares (from CRSP monthly files) to compute monthly turnover for each stock in each industry. Using the month-end market capitalizations we compute value-weighted 
Table 6

Herding Levels and Investor Sentiment.

\begin{tabular}{|c|c|c|c|c|c|c|c|c|c|}
\hline & \multicolumn{3}{|c|}{ At least 5 active mutual funds } & \multicolumn{3}{|c|}{ At least 20 active mutual funds } & \multicolumn{3}{|c|}{ At least 50 active mutual funds } \\
\hline & High & Low & Difference & High & Low & Difference & High & Low & Difference \\
\hline \multicolumn{10}{|c|}{$\begin{array}{l}\text { Panel A. LSV herding measure } \\
\text { Herding measure }\end{array}$} \\
\hline $\begin{array}{l}\text { Mean } \\
t \text {-Stat }\end{array}$ & $\begin{array}{l}0.01718 \\
(20.94)\end{array}$ & $\begin{array}{l}0.01484 \\
(19.56)\end{array}$ & $\begin{array}{l}0.00234 \\
(2.09)\end{array}$ & $\begin{array}{l}0.01626 \\
(21.4)\end{array}$ & $\begin{array}{l}0.01504 \\
(19.94)\end{array}$ & $\begin{array}{l}0.00122 \\
(1.14)\end{array}$ & $\begin{array}{l}0.01558 \\
(22.22)\end{array}$ & $\begin{array}{l}0.01519 \\
(20.65)\end{array}$ & $\begin{array}{l}0.00038 \\
(0.38)\end{array}$ \\
\hline $\begin{array}{c}\text { Buy herc } \\
\text { Mean } \\
\text { t-Stat }\end{array}$ & $\begin{array}{l}\text { easure } \\
0.01574 \\
(13.55)\end{array}$ & $\begin{array}{l}0.01498 \\
(13.43)\end{array}$ & $\begin{array}{l}0.00076 \\
(0.47)\end{array}$ & $\begin{array}{l}0.01469 \\
(13.63)\end{array}$ & $\begin{array}{l}0.01516 \\
(13.62)\end{array}$ & $\begin{array}{l}-0.00047 \\
(-0.30)\end{array}$ & $\begin{array}{l}0.01529 \\
(14.95)\end{array}$ & $\begin{array}{l}0.01527 \\
(13.97)\end{array}$ & $\begin{array}{l}0.00002 \\
(0.01)\end{array}$ \\
\hline $\begin{array}{l}\text { Sell herd } \\
\text { Mean } \\
\text { t-Stat }\end{array}$ & $\begin{array}{l}\text { easure } \\
0.01851 \\
(16.00)\end{array}$ & $\begin{array}{l}0.01471 \\
(14.22)\end{array}$ & $\begin{array}{l}0.00380 \\
(2.45)\end{array}$ & $\begin{array}{l}0.01768 \\
(16.55)\end{array}$ & $\begin{array}{l}0.01493 \\
(14.56)\end{array}$ & $\begin{array}{l}0.00275 \\
(1.86)\end{array}$ & $\begin{array}{l}0.01584 \\
(16.44)\end{array}$ & $\begin{array}{l}0.01512 \\
(15.24)\end{array}$ & $\begin{array}{l}0.00072 \\
(0.52)\end{array}$ \\
\hline \multicolumn{10}{|c|}{$\begin{array}{l}\text { Panel B. SIAS herding measure } \\
\text { Total cross-sectional correlation }\end{array}$} \\
\hline $\begin{array}{l}\text { Mean } \\
t \text {-Stat }\end{array}$ & $\begin{array}{l}0.24798 \\
(8.32)\end{array}$ & $\begin{array}{l}0.21954 \\
(7.67)\end{array}$ & $\begin{array}{l}0.02844 \\
(0.81)\end{array}$ & $\begin{array}{l}0.26004 \\
(11.11)\end{array}$ & $\begin{array}{l}0.22903 \\
(7.91)\end{array}$ & $\begin{array}{l}0.03100 \\
(0.89)\end{array}$ & $\begin{array}{l}0.31199 \\
(14.46)\end{array}$ & $\begin{array}{l}0.28122 \\
(13.47)\end{array}$ & $\begin{array}{l}0.03077 \\
(1.05)\end{array}$ \\
\hline $\begin{array}{c}\text { Mutual } \\
\text { Mean } \\
t-S t a t\end{array}$ & $\begin{array}{c}\text { ollowing t } \\
0.06379 \\
(11.63)\end{array}$ & $\begin{array}{l}\text { ves } \\
0.05453 \\
(11.51)\end{array}$ & $\begin{array}{l}0.00926 \\
(1.64)\end{array}$ & $\begin{array}{l}0.05406 \\
(13.31)\end{array}$ & $\begin{array}{l}0.04968 \\
(13.74)\end{array}$ & $\begin{array}{l}0.00438 \\
(1.14)\end{array}$ & $\begin{array}{l}0.04943 \\
(12.73)\end{array}$ & $\begin{array}{l}0.04334 \\
(15.31)\end{array}$ & $\begin{array}{l}0.00609 \\
(1.90)\end{array}$ \\
\hline $\begin{array}{c}\text { Mutual } \\
\text { Mean } \\
\text { t-Stat }\end{array}$ & $\begin{array}{l}\text { ollowing o } \\
0.18419 \\
(6.42)\end{array}$ & $\begin{array}{l}0.16501 \\
(5.31)\end{array}$ & $\begin{array}{l}0.01918 \\
(0.56)\end{array}$ & $\begin{array}{l}0.20598 \\
(8.90)\end{array}$ & $\begin{array}{l}0.17935 \\
(5.93)\end{array}$ & $\begin{array}{l}0.02662 \\
(0.77)\end{array}$ & $\begin{array}{l}0.26256 \\
(12.82)\end{array}$ & $\begin{array}{l}0.23788 \\
(11.45)\end{array}$ & $\begin{array}{l}0.02468 \\
(0.86)\end{array}$ \\
\hline
\end{tabular}

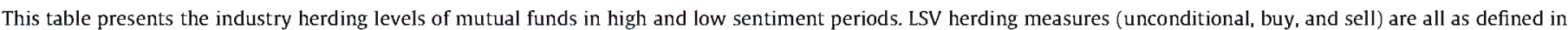

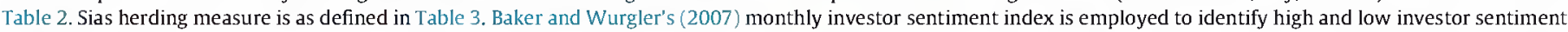

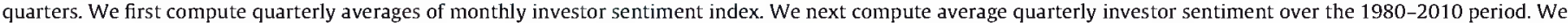

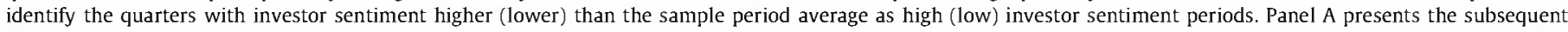

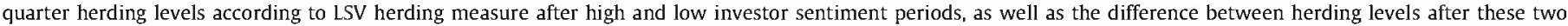

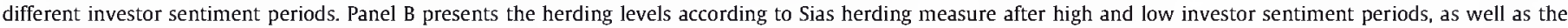

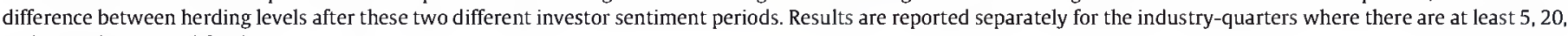
and 50 active mutual funds.

turnover for each industry-month. We then compute quarterly turnover for each industry by averaging the monthly industry turnover in each quarter. After computing quarterly industry turnover we again identify high-mid-low turnover quarters for each industry. Panel $C$ of Table 7 presents the average LSV herding measures for the high-mid-low industry turnover groups, as well as the difference between the average herding levels in high and low industry turnover groups. The results presented in this panel indicate that there is no significant effect of industry turnover on industry herding. ${ }^{30}$

We also perform similar analysis to examine the effect of industry conditions on industry herding in the Sias framework. However, we find no significant effect of industry conditions on industry herding using Sias herding measure. ${ }^{31}$

To sum up, we find evidence that industry return and industry volatility affect industry herding by mutual funds in the subsequent quarter. Mutual funds tend to buy industries in herds after high industry returns and high industry volatility periods. However, industry conditions do not affect the extent to which mutual funds' chase previous quarter industry trades of other mutual funds. These findings suggest that managers' tendency to buy in herds increases following good news in order to avoid a potential criticism of having low ability, by claiming that they made good investment choices similar to those made by other managers. Periods of high industry volatility may indicate periods of greater flow of information and higher information uncertainty (e.g., Ross, 1989; Zhang, 2006). Industry herding following these periods might rise as some managers may find it more difficult to interpret new information and instead mimic their peers in order to avoid a possible underperformance.

\section{Does mutual fund herding in industries destabilize industry market values?}

Previous empirical studies report positive contemporaneous relationship between institutional herding and stock returns, that is, stocks bought by herds outperform stocks sold by herds (e.g., Wermers, 1999; Nofsinger and Sias, 1999; Sias, 2004). These studies also find that stocks bought by herds continue to outperform stocks sold by herds in the short term with no subsequent return reversals and conclude that herding by institutions (and mutual funds) at the stock level does not drive stock prices away from their fundamentals. In contrast, Dasgupta et al. (2011a,b) and Gutierrez and Kelley (2008) document that persistent herding by institutions in stocks can drive stock prices away from their fundamentals.

There is also a theoretical paper by Dasgupta et al. (2011a,b) which suggests that reputational herding by institutions can cause short-term return continuation and long term return reversal in the stocks that experience high levels of herding. However, according to their model, institutional herding is driven by institutional managers' reputational motivations. If herding occurs as a result of correlated signals received by institutional managers, the impact of herding on prices can be quite different. Specifically, for the herding at the industry level, which is the focus of this paper, if mutual funds trade based on the new information which is yet to disseminate across all stocks within an industry, we do not expect a destabilizing effect of industry herding on industry values. We, therefore, test the following hypothesis: 
Table 7

Industry conditions and industry herding.

\begin{tabular}{|c|c|c|c|c|}
\hline & High & Mid & Low & Diff. \\
\hline \multicolumn{5}{|c|}{$\begin{array}{l}\text { Panel A. Industry retum } \\
\text { Herding measure (HM) }\end{array}$} \\
\hline $\begin{array}{l}\text { Mean } \\
\text { t-Stat }\end{array}$ & $\begin{array}{l}0.01667 \\
(21.19)\end{array}$ & $\begin{array}{l}0.01537 \\
(19.70)\end{array}$ & $\begin{array}{l}0.01325 \\
(14.02)\end{array}$ & $\begin{array}{l}0.00342 \\
(2.78)\end{array}$ \\
\hline $\begin{array}{c}\text { Buy herdi } \\
\text { Mean } \\
\text { t-Stat }\end{array}$ & $\begin{array}{l}0.01697 \\
(14.24)\end{array}$ & $\begin{array}{l}0.01673 \\
(14.51)\end{array}$ & $\begin{array}{l}0.01034 \\
(8.34)\end{array}$ & $\begin{array}{l}0.00663 \\
(3.85)\end{array}$ \\
\hline $\begin{array}{c}\text { Sell herdi } \\
\text { Mean } \\
t \text {-Stat }\end{array}$ & $\begin{array}{l}0.01639 \\
(15.84)\end{array}$ & $\begin{array}{l}0.01412 \\
(13.36)\end{array}$ & $\begin{array}{l}0.01600 \\
(11.36)\end{array}$ & $\begin{array}{l}0.00038 \\
(0.22)\end{array}$ \\
\hline $\begin{array}{c}\text { Panel } B .1 \\
\text { Herding } 1 \\
\text { Mean } \\
t \text {-Stat }\end{array}$ & $\begin{array}{l}0.01669 \\
(20.17)\end{array}$ & $\begin{array}{l}0.01522 \\
(19.00)\end{array}$ & $\begin{array}{l}0.01390 \\
(16.24)\end{array}$ & $\begin{array}{l}0.00279 \\
(2.34)\end{array}$ \\
\hline $\begin{array}{c}\text { Buy herd } \\
\text { Mean } \\
\text { t-Stat }\end{array}$ & $\begin{array}{l}0.01678 \\
(13.77)\end{array}$ & $\begin{array}{l}0.01618 \\
(13.56)\end{array}$ & $\begin{array}{l}0.01228 \\
(10.31)\end{array}$ & $\begin{array}{l}0.00450 \\
(2.64)\end{array}$ \\
\hline $\begin{array}{c}\text { Sell herdi } \\
\text { Mean } \\
\text { t-Stat }\end{array}$ & $\begin{array}{l}0.01661 \\
(14.80)\end{array}$ & $\begin{array}{l}0.01435 \\
(13.31)\end{array}$ & $\begin{array}{l}0.01541 \\
(12.58)\end{array}$ & $\begin{array}{l}0.00120 \\
(0.72)\end{array}$ \\
\hline $\begin{array}{c}\text { Panel C. } \\
\text { Herding } ~ \\
\text { Mean } \\
\text { t-Stat }\end{array}$ & $\begin{array}{l}0.01509 \\
(20.74)\end{array}$ & $\begin{array}{l}0.01686 \\
(19.92)\end{array}$ & $\begin{array}{l}0.01378 \\
(14.77)\end{array}$ & $\begin{array}{l}0.00131 \\
(1.11)\end{array}$ \\
\hline $\begin{array}{c}\text { Buy herd } \\
\text { Mean } \\
\text { t-Stat }\end{array}$ & $\begin{array}{l}0.01623 \\
(14.65)\end{array}$ & $\begin{array}{l}0.01453 \\
(12.18)\end{array}$ & $\begin{array}{l}0.01446 \\
(10.79)\end{array}$ & $\begin{array}{l}0.00176 \\
(1.01)\end{array}$ \\
\hline $\begin{array}{c}\text { Sell herd } \\
\text { Mean } \\
t \text {-Stat }\end{array}$ & $\begin{array}{l}0.01395 \\
(14.82)\end{array}$ & $\begin{array}{l}0.01882 \\
(15.83)\end{array}$ & $\begin{array}{l}0.01311 \\
(10.10)\end{array}$ & $\begin{array}{l}0.00084 \\
(0.53)\end{array}$ \\
\hline
\end{tabular}

This table presents the industry conditions and the industry herding levels of mutual funds in LSV framework for industry-quarters where there are at least 50 active mutual funds. LSV herding measures (unconditional, buy, and sell) are all as defined in Table 2 . Panel A presents the herding levels according to LSV herding measures in high, mid, and low industry return periods. To identify high-mid-low return periods for each industry we rank the quarterly value weighted returns of each industry over our sample period into three groups (high-mid-low industry returns). First, second, and third column presents the average subsequent quarter LSV herding measures for these high, mid, low return groups, respectively. The last column reports the average difference between the herding levels of high and low industry return groups. Panel B presents the results of the similar analysis for high, mid, and low industry volatility periods. To identify high-mid-low volatility periods for each industry we rank the quarterly volatility of each industry over our sample period into three groups. Quarterly volatility is defined as the standard deviation of daily (value weighted) industry returns for each industryquarter. Panel $\mathrm{C}$ presents the results of the similar analysis for high, mid, and low industry turnover periods. We divide monthly volume by the number of outstanding shares to compute monthly turnover for each stock in each industry. Using the month-end market capitalizations we compute value-weighted turnover for each industry-month. Quarterly turnover for each industry is computed by averaging the monthly industry turnover in each quarter.

H4. Herding at the industry level by mutual funds does not drive industry values away from their fundamentals.

To test this hypothesis, we first rank industries according to their previous quarter buy and sell LSV herding levels (Eqs. (4) and (5)). We form portfolios of top five industries that experience the highest level of buy (sell) herding. We then compute the equalweighted average of value weighted industry returns for these portfolios in the quarters following the herding. We also form a difference portfolio which buys the top five buy and shorts the top five sell herding industries. Jegadeesh and Titman's (1993) calendar time aggregation method is used to calculate the average returns of these three industry portfolios for overlapping observations. ${ }^{32}$ All of the above defined portfolios are rebalanced quarterly.

Table 8, Panel A, presents the monthly raw returns as well as the CAPM, Fama-French three-factor (Fama and French, 1993), and four-factor alphas (Carhart, 1997) for these three portfolios. The corresponding $t$-statistics are reported in parentheses. The first row of Panel A presents the contemporaneous returns and alphas for the formation period in which top five buy and sell herding industries are identified. The raw returns and the alphas for the formation period are positive and statistically significant for the difference portfolio. The mean monthly raw return as well as the monthly CAPM, three-factor, and four-factor alphas for the difference portfolio are $1.00 \%, 0.96 \%, 0.96 \%$, and $1.18 \%$, respectively, which are also economically significant. This finding is consistent with prior studies that find a contemporaneous positive relationship between returns and herding by mutual funds and institutions. The next rows present the results for subsequent quarter $\left(q_{1}\right)$. The difference portfolio continues to earn positive returns in quarter $\mathrm{q}_{1}$ albeit not statistically significantly different from zero. We also compute the returns in quarters $q_{2}, q_{3}-q_{4}, q_{5}-q_{8}$, and $\mathrm{q}_{9}-\mathrm{q}_{12}$, and find that the difference portfolio's returns are not significantly different from zero in the subsequent periods. It can be therefore inferred that there is no evidence of return reversals for the industries that experience high levels of buy and sell herding. ${ }^{33}$

Panel B of Table 8 repeats the analysis in the Sias framework. Since the Sias herding measure cannot be calculated for each industry-quarter we compute the contributions of each industry 


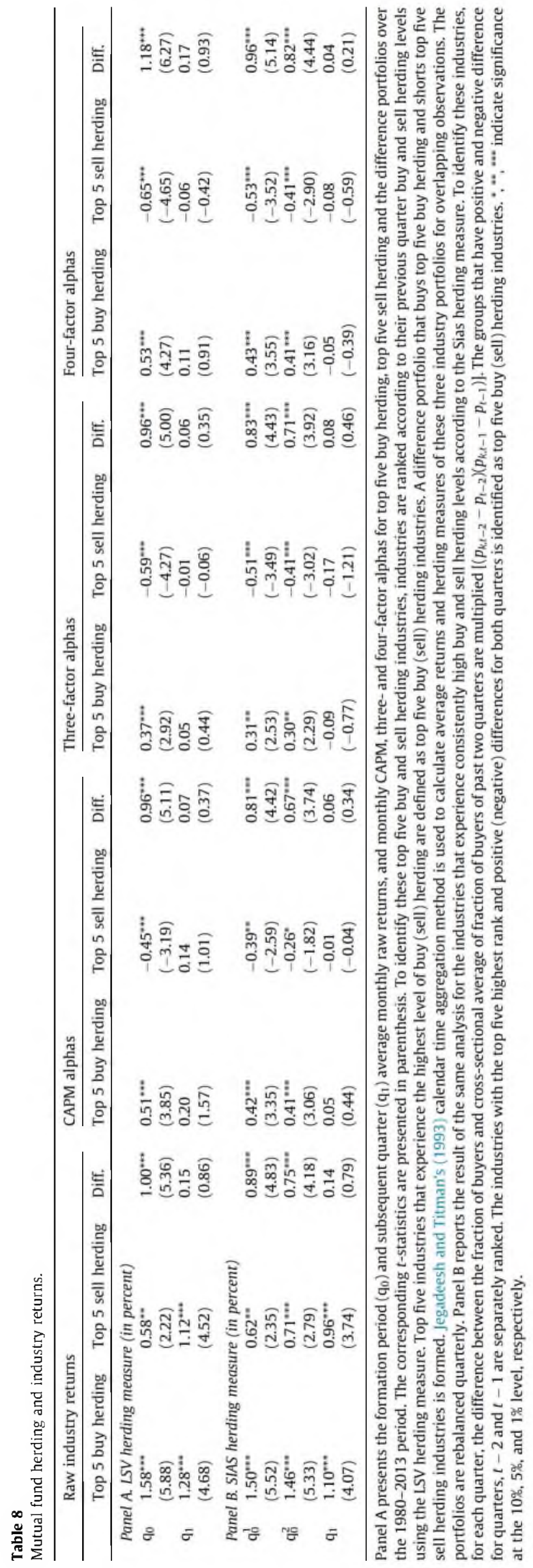

to the cross-sectional correlation for each consecutive pairs of quarters. To distinguish between buy and sell herding industries we rank these contributions separately for the industries with positive and negative differences for both quarters, $q_{0}^{1}$ and $q_{0}^{2}$ (formation quarters). To identify these industries, for each quarter, we multiply the difference between the fraction of buyers and cross-sectional average of the fraction of buyers over the two formation quarters $\left[\left(p_{k, t-2}-\right.\right.$ $\left.\left.-p_{t-2}\right)\left(p_{k, t-1}-p_{t-1}\right)\right]$. We separately rank the industries that have positive and negative differences for both quarters, $q_{0}^{1}$ and $q_{0}^{2}$. The industries with the top five highest contributions among the ones with positive (negative) differences for both quarters are identified as top five buy (sell) herding industries. The first two rows of Panel B present the average raw returns as well as CAPM, three-factor, and four-factor alphas during the formation quarters. As in Panel A, the difference portfolio has positive and statistically significant raw and abnormal returns in the formation quarters. Raw returns for the difference portfolio are $0.89 \%$ and $0.75 \%$ for quarters $q_{0}^{1}$ and $q_{0}^{2}$, respectively, and the various monthly alphas for these formation quarters range between $0.67 \%$ and $0.96 \%$. Panel $B$ also presents the results for the subsequent quarter $\left(q_{1}\right)$. In quarter $q_{1}$ the difference portfolio's raw and abnormal returns are positive, but not significantly different from zero. The difference portfolio continues to earn returns that are not significantly different from zero in periods $\mathrm{q}_{2}, \mathrm{q}_{3^{-}}$ $\mathrm{q}_{4}, \mathrm{q}_{5}-\mathrm{q}_{8}$, and $\mathrm{q}_{9}-\mathrm{q}_{12}$, indicating no evidence of return reversal. ${ }^{34}$

The findings in Table 8 point to a positive contemporaneous relationship between industry herding and industry returns. There is no evidence of return reversals in industries that experience high levels of buy and sell herding. Therefore, the hypothesis that herding does not drive industry values away from fundamentals (hypothesis 4 ) cannot be rejected.

\section{Does mutual fund herding in industries contribute to industry momentum?}

Moskowitz and Grinblatt (1999) show that industries that performed well (poorly) over the previous six-months continue to perform well (poorly) over the subsequent six to twelve month period. One of the potential explanations they offer for this phenomenon is that information may not diffuse simultaneously into the stock prices within the same industry. Information is likely to be first incorporated into the prices of larger firms and then into the prices of other firms. They argue that this lead and lag effect within the leaders and other firms in industries can cause the observed momentum effect in industry returns. This lead and lag effect within industries can also result in industry herding. We argue that industry herding and industry momentum can be related and therefore we test the following hypothesis.

H5. Industry momentum is related to mutual fund herding at the industry level.

Although there is no empirical evidence in the literature about the relationship between momentum and herding at the industry level, Nofsinger and Sias (1999) document that momentum is related to institutional herding at the individual stock level. More specifically, they find that winners (losers) that experience largest subsequent institutional ownership increase (decrease) exhibit the strongest momentum. In this section, we explore the relationship between momentum and herding at the industry level by employing a similar methodology.

We first examine whether there is any evidence of industry momentum when industries are classified according to Fama and French 49 industry classification. We then investigate whether holding period returns of winner and loser industries differ based 
Table 9

Industry herding and industry momentum-( 6 month formation/ 6 month holding).

\begin{tabular}{|c|c|c|c|c|c|}
\hline & Industry momentum & High herding & Intermediate herding & Low herding & High-low \\
\hline \multicolumn{6}{|c|}{ Panel A. Raw returns (in percent) } \\
\hline Past loser industries & $\begin{array}{l}0.91^{* * *} \\
(3.28)\end{array}$ & $\begin{array}{l}0.89^{* * *} \\
(3.13)\end{array}$ & $\begin{array}{l}0.90^{* * *} \\
(3.16)\end{array}$ & $\begin{array}{l}0.95^{* * *} \\
(3.17)\end{array}$ & $\begin{array}{l}-0.06 \\
(-0.37)\end{array}$ \\
\hline Past winner industries & $\begin{array}{l}1.23^{* * * *} \\
(4.97)\end{array}$ & $\begin{array}{l}1.38^{* * * *} \\
(5.26)\end{array}$ & $\begin{array}{l}1.29^{\text {***k }} \\
(5.07)\end{array}$ & $\begin{array}{l}1.03^{* * *} \\
(3.96)\end{array}$ & $\begin{array}{l}0.35^{\text {***** }} \\
(2.67)\end{array}$ \\
\hline Winners-losers & $\begin{array}{l}0.32^{*} \\
(1.77)\end{array}$ & $\begin{array}{l}0.49^{* * *} \\
(2.25)\end{array}$ & $\begin{array}{l}0.39^{* * *} \\
(2.01)\end{array}$ & $\begin{array}{l}0.08 \\
(0.37)\end{array}$ & $\begin{array}{l}0.41^{* * *} \\
(1.97)\end{array}$ \\
\hline \multicolumn{6}{|c|}{ Panel B. CAPM alphas (in percent) } \\
\hline Past loser industries & $\begin{array}{l}-0.15 \\
(-1.23)\end{array}$ & $\begin{array}{l}-0.15 \\
(-1.00)\end{array}$ & $\begin{array}{l}-0.17 \\
(-1.26)\end{array}$ & $\begin{array}{l}-0.14 \\
(-0.86)\end{array}$ & $\begin{array}{l}-0.02 \\
(-0.12)\end{array}$ \\
\hline Past winner industries & $\begin{array}{l}0.23^{* *} \\
(2.15)\end{array}$ & $\begin{array}{l}0.39^{* * *} \\
(2.71)\end{array}$ & $\begin{array}{l}0.28^{* *} \\
(2.43)\end{array}$ & $\begin{array}{l}0.03 \\
(0.23)\end{array}$ & $\begin{array}{l}0.36^{\text {**** }} \\
(2.69)\end{array}$ \\
\hline Winners-losers & $\begin{array}{l}0.39^{* *} \\
(2.15)\end{array}$ & $\begin{array}{l}0.54^{* *} \\
(2.48)\end{array}$ & $\begin{array}{l}0.46^{* *} \\
(2.34)\end{array}$ & $\begin{array}{l}0.17 \\
(0.76)\end{array}$ & $\begin{array}{l}0.38^{*} \\
(1.80)\end{array}$ \\
\hline \multicolumn{6}{|c|}{ Panel C. Three-factor alphas (in percent) } \\
\hline Past loser industries & $\begin{array}{l}-0.32^{* * *} \\
(-2.70)\end{array}$ & $\begin{array}{l}-0.30^{* *} \\
(-1.99)\end{array}$ & $\begin{array}{l}-0.30^{* *} \\
(-2.21)\end{array}$ & $\begin{array}{l}-0.36^{* *} \\
(-2.46)\end{array}$ & $\begin{array}{l}0.06 \\
(0.40)\end{array}$ \\
\hline Past winner industries & $\begin{array}{l}0.14 \\
(1.35)\end{array}$ & $\begin{array}{l}0.25^{*} \\
(1.83)\end{array}$ & $\begin{array}{l}0.20^{*} \\
(1.75)\end{array}$ & $\begin{array}{l}-0.03 \\
(-0.22)\end{array}$ & $\begin{array}{l}0.28^{* *} \\
(2.10)\end{array}$ \\
\hline Winners-losers & $\begin{array}{l}0.46^{* *} \\
(2.54)\end{array}$ & $\begin{array}{l}0.55^{* *} \\
(2.50)\end{array}$ & $\begin{array}{l}0.50^{* *} \\
(2.53)\end{array}$ & $\begin{array}{l}0.34 \\
(1.54)\end{array}$ & $\begin{array}{l}0.22 \\
(1.05)\end{array}$ \\
\hline \multicolumn{6}{|c|}{ Panel $D$. The ratio of number of buyers to total number of buyers and sellers } \\
\hline Past loser industries & 0.5151 & 0.5072 & 0.5108 & 0.5274 & -0.0203 \\
\hline Past winner industries & 0.5116 & 0.5219 & 0.5091 & 0.5039 & 0.0180 \\
\hline Winners-losers & $\begin{array}{l}-0.0035 \\
(-1.19)\end{array}$ & $\begin{array}{l}0.0147^{* * *} \\
(3.22)\end{array}$ & $\begin{array}{l}-0.0017 \\
(-0.46)\end{array}$ & $\begin{array}{l}-0.0235^{* * *} \\
(-4.46)\end{array}$ & $\begin{array}{l}0.0382^{* * *} \\
(5.57)\end{array}$ \\
\hline
\end{tabular}

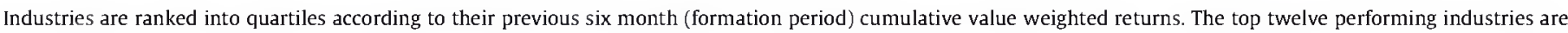

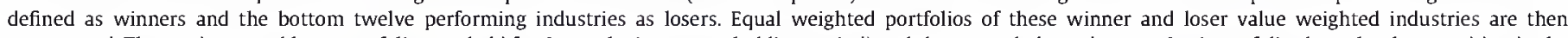

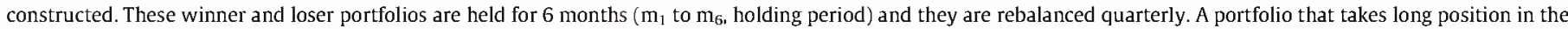

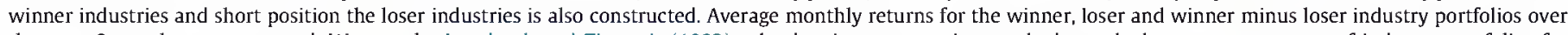

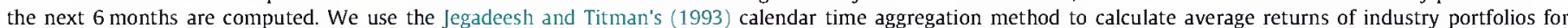

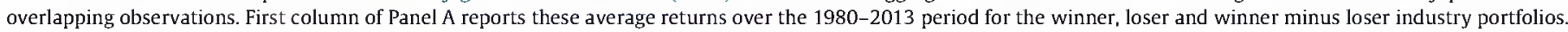

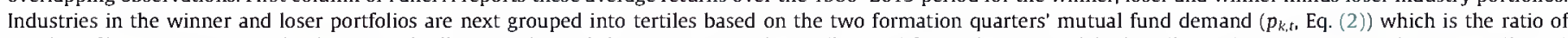

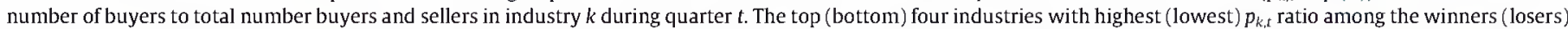

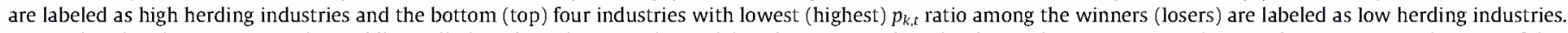

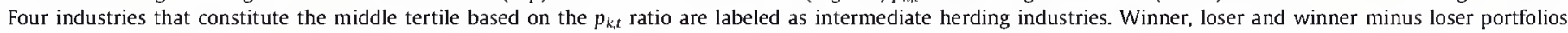

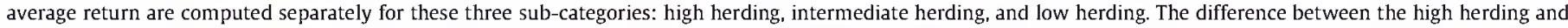

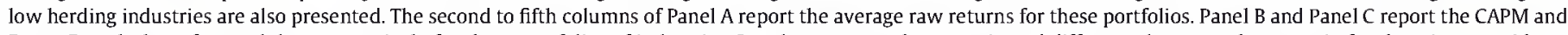

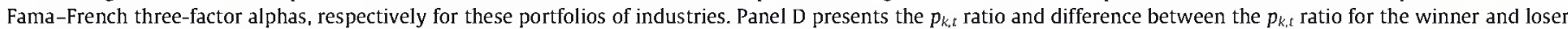

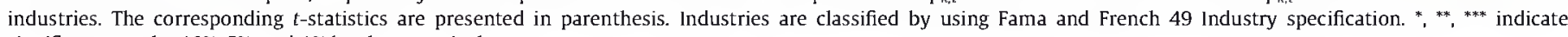
significance at the $10 \%, 5 \%$, and $1 \%$ level, respectively.

on the level of mutual fund demand (Eq. (2)) that they experience during the formation period. ${ }^{35}$

We start by ranking industries into quartiles according to their previous six month (formation period; $m_{-5}$ to $m_{0}$, where $m_{0}$ is the last month of the formation period) cumulative value weighted returns. $^{36}$ The top twelve performing industries are defined as winners and the bottom twelve performing industries as losers. We then construct equal weighted portfolios of these winner and loser value weighted industries. These winner and loser portfolios are held for the next six months (holding period, $m_{1}$ to $m_{6}$ ) and they are rebalanced quarterly. ${ }^{17}$ We also construct a portfolio that takes long position in the winner industries and short position in the loser industries. We compute average monthly returns for the winner, loser and winner minus loser industry portfolios over the next six months. As in Moskowitz and Grinblatt (1999), average monthly returns of each industry are value weighted, but the winner and loser industry portfolios are equal weighted. We employ Jegadeesh and Titman's (1993) calendar time aggregation method to calculate average returns of industry portfolios for overlapping observations. First column of Panel $A$ of Table 9 reports these average returns of the winner, loser, and winner minus loser industry portfolios over the 1980-2013 period. The winner minus loser portfolio earns a monthly average return of $0.32 \%$ and it is statistically significant at the $10 \%$ level. We also compute CAPM and three-factor alphas of these three portfolios and present the results in the first columns of Panels B and C, respectively. The CAPM and the three factor alpha of the winner minus loser (momentum) portfolio is $0.39 \%$ and $0.46 \%$, respectively and both are statistically significant at the $5 \%$ level.

We next group winner and loser industries into tertiles based on their mutual fund demand ( $p_{k_{L}}$, Eq. (2)), the ratio of the number of buyers to total number of buyers and sellers in industry $k$ during quarter $t$, during the two quarters of the formation period. The top (bottom) four industries with highest (lowest) mutual fund demand among the winners (losers) are labeled as high herding industries and the bottom (top) four industries with lowest (highest) mutual fund demand among the winners (losers) are labeled as low herding industries. The four industries that constitute the middle tertile based on the mutual fund demand are labeled as intermediate herding industries. We repeat the above analyses for the winner, loser and winner minus loser portfolios separately 
for these three sub-categories: high herding, intermediate herding, and low herding. We also compute the difference between the high herding and low herding industries. ${ }^{38}$

The second to fourth columns of Panel A of Table 9 report the average raw returns of the loser, winner, and winner minus loser portfolios separately for the three herding groups: high herding, intermediate herding, and low herding industries. The last column reports the difference between high and low herding groups for these portfolios. In Panels B and C, we report the CAPM and three factor alphas, respectively for these portfolios. As can be seen from the three panels of Table 9, for the high and intermediate herding industries winner minus loser portfolios earn positive and statistically significant average raw returns, CAPM alphas, and three-factor alphas. However, for the low herding industries there is no evidence of industry momentum - the average raw return, CAPM and three-factor alphas for this winner minus loser portfolio of low herding industries are not significantly different from zero. The difference between the average momentum returns of high herding and low herding industries is $0.41 \%$ and statistically significant at the $5 \%$ level, and this difference is marginally significant after adjusting for market risk. ${ }^{39}$ This difference between momentum returns is mainly driven by the difference between the returns of winner industries. The difference between average returns of high herding and low herding winner portfolios is $0.35 \%$ and statistically significant at the $1 \%$ level. In contrast, there is no significant difference between the returns of high herding and low herding loser industries. This indicates that winner industries with low mutual fund demand (low herding) during the formation period do not continue to earn superior returns in the subsequent six months. In contrast, winner industries that experience high mutual fund demand (high herding) during the last quarter of the formation period continue to earn abnormal returns in the following six month period. These results are in support of hypothesis $5 .{ }^{40}$

We also explore the mutual fund demand in the subsequent quarter (first quarter of the holding period) for the winner and loser industries. These results are reported in Panel D of Table 9. We find no significant difference between the subsequent mutual fund demand for winner and loser industries as can be seen in the first column of Panel D. However, mutual fund demand for winner industries in the first quarter of the holding period is significantly higher (lower) than that for loser industries with high (low) herding. This finding suggests that winner industries that experience high (low) demand in the formation period continue to experience higher (lower) demand than loser industries do in the first quarter of the holding period, consistent with the evidence of industry herding reported in Section 4.1.2.

To sum up, in this section we provide evidence that industry momentum in the first six months of the year after the formation period is mainly observed in industries that experience high herding (high mutual fund demand) during the formation period. There is no evidence of momentum in industries that experience low herding during the formation period. This difference between the momentum returns of high and low herding industries is primarily driven by the difference between the subsequent returns of winner industries.

\section{Conclusion}

Using the LSV (1992) and the Sias (2004) herding measures this study documents that mutual funds engage in industry herding. Monte Carlo simulations provide strong evidence that observed levels of industry herding are significantly higher than what could be expected by chance. We further document that industry herding by mutual funds is not driven by fund flows or style investing and is not a manifestation of individual stock herding.

This study also comments on the relationship between mutual fund herding and the returns on the herded industries. We document that industries that are bought by herding mutual funds outperform industries that are sold by herding mutual funds in the quarter in which herding takes place. We find no evidence of return reversals for these industries, indicating that mutual fund herding has no destabilizing effect on industry values. Finally, this paper makes a contribution to the vast momentum literature by showing that industry momentum in winner industries depends on the extent that mutual funds herd away or to these winner industries during the formation period.

The findings of this study also have important implications for both individual investors and institutional investors especially for the ones who implement industry strategies. These investors may benefit from incorporating the information that mutual funds herd in industries and that certain conditions are associated with such herding behavior into their industry strategies. The evidence provided in this paper is also important for the mutual fund investors as it suggests that actively managed mutual funds follow the crowd when they trade industries. This information would be valuable to fund investors especially if herding in industries affects fund performance and the tendency of funds to engage in such behavior is predictable.

\section{References}

Baker, M., Wurgler, J., 2007. Investor sentiment in the stock market. Journal of Economic Perspective 21 (2), 129-152.

Barberis, N., Shleifer, A., 2003. Style investing. Journal of Financial Economics 68 (2), $161-199$.

Barras, L., Scaillet, O., Wermers, R, 2010. False discoveries in mutual fund performance. Measuring luck in estimated alphas. Journal of Finance 65, 179216.

Bikhchandani, S., Hirshleifer, D. Welch, I., 1992. A theory of fads, fashion, custom, and cultural change as informational cascades. Journal of Political Economy 100 , $992-1026$

Brown, C., Wei, K., Wermers, R., 2014. Analyst recommendations, mutual fund herding and overreaction in stock prices. Management Science 60 (1), 1-20.

Carhart, M., 1997. On persistence in mutual fund performance. Journal of Finance $52,57-82$.

Chang, C.E., Cheng, J.W., Khorana, A., 2000. An examination of herd behavior in equity markets: An international perspective. Journal of Banking and Finance 24, 1651-1679.

Chevalier, J., Ellison, G., 1999. Career concerns of mutual fund managers. Quarterly Journal of Economics 114, 389-432.

Chiang, T.C., Zheng, D., 2010. An empirical analysis of herd behavior in global stock markets. Journal of Banking and Finance 34, 1911-1921.

Choi, N., Sias, R., 2009. Institutional industry herding. Journal of Financial Economics 94, 469-491.

Christie, W.G., Huang, R.D., 1995. Following the pied piper: Do individual returns herd around the market? Financial Analysts Journal 51, 31-37.

Coval, J., Stafford, E., 2007. Asset fire sales (and purchases) in equity markets. Journal of Financial Economics 86, 479-512.

Dasgupta, A., Prat, A., Verardo, M., 2011a. Institutional trade persistence and longterm equity returns. Jourmal of Finance $66,635-663$.

Dasgupta, A., Prat, A., Verardo, M., 2011b. The price impact of institutional herding. The Review of Financial Studies 24, 892-925.

Falkenstein, E., 1996. Preferences for stock characteristics as revealed by mutual fund portfolio holdings. Journal of Finance 53, 111-135.

Fama, E., French, K., 1993. Common risk-factors in the returns on stocks and bonds. Journal of Financial Economics 33, 3-56. 
Fama, E., French, K., 1997. Industry costs of equity. Journal of Financial Economics $43,153-193$.

Friedman, B., 1984. A comment: stock prices and social dynamics. Brookings Papers on Economic Activity 2, 504-508.

Friend, I., Blume, M., Crockett, J., 1970. Mutual Funds and Other Institutional Investors. McGraw-Hill, New York, N.Y.

Froot, K., Scharfstein, D., Stein, J., 1992. Herd on the street: Informational inefficiencies in a market with short-term speculation. Journal of Finance 47. 1461-1484.

Froot, K., Teo, M., 2008. Investing style and institutional investors. Journal of Financial and Quantitative Analysis 43 (4), 883-906.

Gavriilidis, K., Kallinterakis, V., Leite Ferreira, M.P., 2013. Institutional industry herding: Intentional or spurious? Journal of International Financial Markets, Institutions and Money 26, 192-214.

Grinblatt, M., Titman, S., Wermer's, R, 1995. Momentum investment strategies, portfolio performance, and herding: A study of mutual fund behavior. American Economic Review 85, 1088-1105.

Gutierrez, R., Kelley, E., 2008. Institutional Herding: Destabilizing Buys, Stabilizing Sells. Working paper, University of Oregon and University of Arizona.

Hirshleifer, D., Subrahmanyam, A., Titman, S., 1994. Security analysis and trading patterns when some investors receive information before others. Journal of Finance 49, 1665-1698.

Hou, K., 2007. Industry information diffusion and the lead-lag effect in stock returns. Review of Financial Studies 20, 1113-1138.

Hwang, S., Salmon, M., 2004. Market stress and herding. Journal of Empirical Finance $11,585-616$

Jegadeesh, N., Titman, S., 1993. Returns to buying winners and selling losers Implications for stock-market efficiency. Journal of Finance 48, 65-91.
Lakonishok, J., Shleifer, A, Vishny, R., 1992. The impact of institutional trading on stock-prices. Journal of Financial Economics 32, 23-43.

Liao, T.L., Huang, C.J., Wu, C.Y., 2011. Do fund managers herd to counter investor sentiment? Journal of Business Research 64, 207-212.

Moskowitz, T., Grinblatt, M., 1999. Do industries explain momentum? Journal of Finance 54, 1249-1290.

Newey, W., West, K., 1987. A simple, positive semi-definite, heteroskedasticity and autocorrelation consistent covariance matrix. Econometrica 55, 703-708.

Nofsinger, J., Sias, R., 1999. Herding and feedback trading by institutional and individual investors. Journal of Finance 54, 2263-2295.

Ross, S.A., 1989. Information and volatility: The No-arbitrage martingale approach to timing and resolution irrelevancy. Journal of Finance 44, 1-17.

Scharfstein, D., Stein, J., 1990. Herd behavior and investment. American Economic Review 80, 465-479.

Sharma, V., Easterwood, J., Kumar, R., 2006. Institutional Herding and the Internet Bubble. Working Paper. Virginia Tech.

Sias, R., 2004. Institutional herding. Review of Financial Studies 17, 165-206.

Shleifer, A., 2000. Inefficient Markets: An Introduction to Behavioral Finance. Oxford University Press, Oxford.

Wermers, R., 1999. Mutual fund herding and the impact on stock prices. Journal of Finance 54, 581-622

Welch, I., 1992. Sequential sales, learning, and cascades. Journal of Finance 47,695732.

Zhang, F.X., 2006. Information uncertainty and stock returns. Journal of Finance 61 $105-137$.

Zwiebel, J., 1995. Corporate conservatism and relative compensation. Journal of Political Economy 103, 1-25. 